\title{
AN ENVIRONMENTALLY HAZARDOUS PROCESS: WHY THE UNITED STATES SHOULD FOLLOW FRANCE'S LEAD AND BAN HYDRAULIC FRACTURING
}

\author{
Morgan R. Whitacre*
}

\section{INTRODUCTION}

The process known today as hydraulic fracturing ("fracking," "hydrofracing," or "fracing") began as early as the 1940s. " Essentially, the fracking process was developed as a way for gas and oil companies to "extract hydrocarbons from 'low-permeability reservoirs,' or natural underground gas chambers that require massive amounts of hydraulic stimulation to recover cost-effective amount[s] of gas and/or oil.", The process of fracking involves several steps. First, a deep well (up to 8,000 feet $^{3}$ is drilled into the earth at a location deemed by a company to have substantial amounts of oil or gas located in the shale of the underlying crust. ${ }^{4}$ Second, a combination of millions of gallons of water, sand, ${ }^{5}$ and highly pressurized fluids and solvents are injected into the well where the fracturing site is located. ${ }^{6}$ There, the chemicals and fluids are discharged at great speeds towards a subterranean reservoir. ${ }^{7}$ The fluid combination is injected against the underground well until at least one fracture appears in the surface of the earth or an existing fracture widens. ${ }^{8}$ After the fractures are created or widened, sand is injected into the seams of the fracture to ensure that the cracks remain open during the extraction process. ${ }^{9}$ This

* J.D. Candidate, Indiana University - McKinney School of Law (2013), B.S. Northern Arizona University (2009). I would like to acknowledge and thank Janet Novatney for her invaluable assistance in editing this Note and mentoring me through the process. I also want to thank Professor Miriam Murphy, Associate Director, Ruth Lilly Law Library, Indiana University Robert H. McKinney School of law for her assistance in my research. Finally, I want to acknowledge and thank my life-partner, Mark Merchant, for his patience, tolerance, and most importantly, love through months of work on this Note.

1. Angela C. Cupas, The Not-So-Safe Drinking Water Act: Why We Must Regulate Hydraulic Fracturing at the Federal Level, 33 WM. \& MARY ENVTL. L. POL'Y Rev. 605, 609 (2009).

2. Id. at 610 .

3. Hydraulic Fracturing FAQs, GASLANDTHEMOVIE.COM, http://www.gaslandthe movie.com/whats-fracking (last visited Feb. 19, 2013) [hereinafter Fracking FAQs].
4. Id.
5. Id.
6. Cupas, supra note 1 , at 610 .
7. Id.
8. Id.
9. Id. 
allows the gas and oil to flow freely from the shale. ${ }^{10}$ The injected fluid ("frac fluid") is drained, to be stored and disposed of later, and gas and oil are captured at the surface. ${ }^{11}$

This Note provides details of the process of hydraulic fracturing, current legislation applicable to fracking in the United States, and reasons supporting an outright ban against hydraulic fracturing throughout the country. Although fracking is a process that has been in use for over sixty years, ${ }^{12}$ it has become a topic of harsh criticism from environmental groups within the last ten years. ${ }^{13}$ The process of drilling into the earth and injecting chemicals has itself faced criticism from leading experts in environmental science, ${ }^{14}$ but other ramifications from the process are now being contemplated. ${ }^{15}$ There are supporting reports that it causes ground water contamination, air pollution, and even seismic disruptions. ${ }^{16}$ In 2010 , the Emmy Award winning movie-documentary Gasland was written and produced in Pennsylvania by Josh Fox, a concerned environmental activist, detailing some of the most egregious examples of groundwater contamination resulting from companies conducting fracking around the United States. ${ }^{17}$ The concern has been so great that many states are looking at implementing moratoriums on the process while more studies are conducted or, in some cases, passing legislation that would fully ban the practice. ${ }^{18}$ Worldwide, France is the only European country heeding the environmental concerns, and thus far has become the leader in

10. Fracking FAQs, supra note 3.

11. Cupas, supra note 1 , at 610 .

12. Seamus McGraw, Is Fracking Safe? The Top 10 Controversial Claims About Natural Gas Drilling, POPUlar MECHANICS, (Nov. 9, 2012), http://www.popularmechanics.com/ science/energy/coal-oil-gas/top-10-myths-about-natural-gas-drilling-6386593\#slide-1 (citing statement of Sen. John Kerry in May 2010).

13. See generally NEW YORKERS AGAINST FRACKING, http://nyagainstfracking.org/ (last visited Mar. 11, 2013) and STUDENTS AgAINST FrACKING, http://studentsagainst fracking.blogspot.com/ (last visited Mar. 11, 2013).

14. See generally NATURAL GAS WATCH, http://www.naturalgaswatch.org/?cat=59 (last visited Mar. 11, 2013) (click "Fracking" then see the vast amounts of articles written criticizing fracking).

15. McGraw, supra note 12 (referencing Claim Two from Green Party of Pennsylvania that fracking squanders natural resources).

16. See infra note 48 , note 73 , and note 58 .

17. GaSLAND. (New Video Group 2010).

18. Sean Hargreaves, NY Set to Lift Fracking Ban, CNNMONEY (July 1, 2011, 2:33 PM), http://money.cnn.com/2011/07/01/news/economy/fracking_new_york/index.htm (noting that currently there is a moratorium on fracking and deep gas exploration in New York although lobbying is currently underway to lift it). See also Angela Delli Santi and Josh Lederman, Chris Christie Fracking Ban: New Jersey Governor Proposes 1 Year Gas Drilling Moratorium, HufFPost GREEN (Aug. 25, 2011, 6:21 PM), http://www.huffingtonpost.com/ 2011/08/25/chris-christie-fracking-ban_n_936822.html (explaining that after the New Jersey governor failed to sign the legislature's bill banning fracking in New Jersey the state adopted a one-year moratorium). 
environmental protectionism by passing a total countrywide ban against fracking in the summer of $2011 .{ }^{19}$ This Note discusses the various statutory and regulatory approaches the United States and individual states within the United States have taken. Additionally, this Note highlights the failure to adequately address the severe environmental consequences related to hydraulic fracturing at both the state and federal levels. Furthermore, in Part V, this Note details the legislative and public policy reasons supporting a French-style ban being legislated federally in the United States. Finally, after conducting a thorough comparative analysis, this Note recommends that the United States adopt a federal ban on hydraulic fracturing.

\section{DETAILS OF FRACKING}

\section{A. Description of Fracking Fluid and the Fracking Process}

Each time the fracking process is conducted in an area, between eighty and 300 tons of chemicals are used. ${ }^{20}$ This "frac fluid" is comprised of hundreds of different types of chemicals, in addition to ninety-nine percent water and one half percent sand. Some of the most controversial chemicals include, but are not limited to: acids (dissolves minerals in the pre-fracked rock); glutaraldehyde (kills bacteria located in the water); N, nDimethyl formamide (prevents corrosion of the pipe); polyacrylamide (minimizes friction between the fluid and the pipe); petroleum distillates ("slicks" the water to minimize friction); guar gum (thickens water to suspend the sand); proppant or sand (allows fissures in the earth to remain open so the gas can escape); and isopropanol (increases the viscosity of the fracture fluid). ${ }^{21}$ After the chemicals are injected into the well and the

19. Tara Patel, France Vote Outlaws 'Fracking' Shale for Natural Gas and Oil Extraction, BLOOMBERG (July 1, 2011, 6:22 AM), http://www.bloomberg.com/news/ 2011-07-01/france-vote-outlaws-fracking-shale-for-natural-gas-oil-extraction.html.

20. Fracking FAQs, supra note 3. See also Jay Kimball, Congress Releases Report on Toxic Chemicals Used In Fracking, 8020 VISION (Apr. 17, 2001), http://8020vision.com/ $2011 / 04 / 17 /$ congress-releases-report-on-toxic-chemicals-used-in-fracking/ (" $[\mathrm{H}]$ orizontal fracking uses up to 300 tons of a mixture of 750 chemicals, many of them proprietary, and millions of gallons of water per frack.").

21. A Fluid Situation: Typical Solution Used In Hydraulic Fracturing, available at http://justbeneaththesurfacewv.com/Resources/Docs/1362-10-IOGA-EID-Fact-Sheet-V.pdf (of the above listed chemicals, the common uses for them include, respectively: swimming pool cleaner, disinfectant and sterilizer for medical equipment; used in pharmaceuticals, acrylic fibers and plastics; used in water treatments and as a soil conditioner; make-up remover and used in laxatives; thickener used in cosmetics, baked goods, ice cream, tooth-paste, sauces, and salad dressing; used for water filtration and in play sand; used as glass cleaner, antiperspirant, and hair color). For a more comprehensive list and effects, see MiNORITY STAFF OF H. COMM. ON ENERGY AND COMmERCE, 111 th CONG. RePORT ON CHEMICALS UsED IN HydRAULIC FraCtuRING (Apr. 18, 2011) available at http://democrats.energycommerce.house.gov/sites/default/files/documents/ Hydraulic\%20Fracturing\%20Report\%204.18.11.pdf. 
fissure is opened, natural gas emerges wet in produced water. It then has to be separated from the wastewater at the surface. ${ }^{22}$ Typically, only thirty to fifty percent of the water is recovered from a well, and many experts say this wastewater can be highly toxic. ${ }^{23}$ Usually, the water is then placed into a holding pond located next to the drilling well where the water evaporates. ${ }^{24}$ Sometimes, the water is placed into a holding tank where it is stored long-term for later use by deep injection in oil and gas waste wells. ${ }^{25}$

\section{B. Places Fracking is Conducted}

Currently, fracking is conducted throughout many areas of the United States. ${ }^{26}$ The areas with the most natural fracking characteristics are shaleconcentrated areas. ${ }^{27}$ Hydrocarbon shale is rich in natural gas deposits. ${ }^{28}$ Natural gas located in shale is produced from shale formations that usually act as the reservoir, and is known as a dry gas composed of at least ninety percent methane. ${ }^{29}$ Natural gas, located in large shale deposits, exists across much of the United States. ${ }^{30}$ Some of the most prominent areas where natural gas fracking is conducted include these large shale areas. ${ }^{31}$ Such areas include, but are not limited to: the Barnett Shale in Texas, the Bossler Shale in Louisiana, the Haynesville Shale in Texas and Louisiana, and the Marcellus Shale in New York, Ohio, Pennsylvania, and West Virginia. ${ }^{32}$ The Barnett Shale is the most prominent shale in the United States, covering approximately 5,000 square miles. ${ }^{33}$ Most of the fracking in contention today involves the Marcellus Shale, which, considering only the portion containing natural gas and petroleum liquids, is approximately,

22. Fracking FAQs, supra note 3; see also Kimball, supra note 20.

23. Fracking FAQs, supra note 3.

24. Id. See also GASLAND, supra note 17.

25. Clean Water Action, Fracking: The Process, http://www.cleanwater.org/page/ fracking-process (last visited Mar. 8, 2013).

26. For a map identifying all the locations where fracking is conducted in the United States see Fracking Across the United States, EARTH JUSTICE, http://earthjustice.org/ features/campaigns/fracking-across-the-united-states (last visited Mar. 8, 2013).

27. Marc Lallanilla, A Brief Chat About Fracking, http://greenliving.about.com/od/ scienceandtechnology/a/Hydraulic-Fracturing-Fracking.htm (last visited Mar. 7, 2013) (scroll down to "Where does hydrofracking take place?").

28. Terry W. Roberson, Feature: The State of Texas Versus the EPA Regulation of Hydraulic Fracturing, 48 HOUSTON LAWYER 24 (2011).

29. Id.

30. $I d$.

31. Id.

32. Hydraulic Fracturing Facts, HydraulicFracturing.COM http://www.hydraulic fracturing.com/Pages/information.aspx (last visited Dec. 27, 2012)[hereinafter Fracturing Facts].

33. Roberson, supra note 28 , at 24 . 
95,000 square miles. $^{34}$

\section{ENVIRONMENTAL CONCERNS WITH FRACKING}

\section{A. Water Usage as a Negative Consequence}

One of the most disturbing statistics regarding the fracking process is the amount of water that is consumed. Generally, anywhere from one to eight million gallons of water may be used to frack a well. ${ }^{35}$ Some experts have estimated that each well drilled in the Barnett Shale consumes approximately three million gallons of fresh water through production and completion, and roughly sixty percent of that water is groundwater. ${ }^{36}$ Some estimates suggest that as much as ninety percent of water used in fracking across the United States is groundwater. ${ }^{37}$ Experts in the fracking process acknowledge that surface water will soon become the primary source of fresh water used for fracking because it is the main water source in shale areas. $^{38}$ One of the greatest concerns among environmental experts is aquifer depletion as a result of water removal, which could affect public and private water supply wells. ${ }^{39}$ For example, when considering total water usage in the Barnett Shale region of the United States, fracking constituted one half percent of all water usage in 2005 , but as drilling increased some experts conservatively estimated that the total water usage could have exceeded $1.7 \%$ by the end of $2010 .^{40}$ This amount of water usage creates concern especially in those areas in the western part of the United States where water is scarce, ${ }^{41}$ and the removal of large volumes of water could stress drinking water supplies. ${ }^{42}$ Eventually, this could lead to harmful, unintended consequences including the lowering of water tables or the dewatering of drinking water aquifers, decreased stream flows, and reduced volumes of water in surface water reservoirs; these activities could have a

34. What Is the Marcellus Shale Formation?, OILSHALEGAS.COM, http://oilshalegas.com/ marcellusshale.html (last visited Mar. 11, 2013) (the shale extends over 575 miles and has a thickness of up to 900 feet).

35. Fracking $F A Q$ s, supra note 3 (noting that "individual wells may be fracked up to eighteen times").

36. Brian J. Smith, Fracing the Environment?: An Examination of the Effects and Regulation of Hydraulic Fracturing, 18 TEX. WESLEYAN L. REV. 129, 132 (2011).

37. Id.

38. Id. at 133 .

39. Id. at 139 .

40. Id at 133 .

41. GASLAND, supra note 17.

42. U.S. Envtl. Prot. Agency, Plan to Study the Potential Impacts of Hydraulic FRACTURING ON DRINKING WATER RESOURCES (2011), available at http://www.epa.gov/hfstudy/HF_Study_Plan_110211_FINAL_508.pdf [hereinafter EPA's Plan TO STUDY]. 
long-term negative impact on available drinking water in areas where hydraulic fracturing is occurring. ${ }^{43}$

\section{B. Ground Water Contamination as a Consequence}

Some of the greatest concerns regarding fracking are centered on the ability of frac fluids and gas to migrate into the groundwater, contaminating the drinking water once they are released underground. These concerns are based on several factors. ${ }^{44}$ These include: the fluid flow; the toxicity and radioactivity of prodúced water from a mixture of fracturing fluids and deep saline formation waters that can discharge; the potential explosion and asphyxiation hazard of natural gas; and the large number of private wells in rural areas that rely on shallow groundwater for household and agricultural uses that are typically unregulated and untested. ${ }^{45}$ One result of surface and groundwater contamination that can occur from fracking is due to fracking additives being released into groundwater because of the failure of drilling companies to have proper storm controls at the well site. ${ }^{46}$ Furthermore, ineffective site management, ineffective subsurface and fluid contaminant practices, poor well construction, and accidental spills may also result in groundwater contamination. ${ }^{47} \mathrm{~A}$ recent study conducted by the Center For Global Change at Duke University of sixty-eight private wells located in the Marcellus Shale showed evidence of methane contamination of shallow drinking water systems located near hydraulic fracturing well sites. ${ }^{48}$ The study compared groundwater quality from areas currently exploited for gas by hydraulic fracturing to those that are not currently associated with gas drilling. ${ }^{49}$ The study concluded that the water extracted from shallow well

43. Id.

44. Stephen G. Osborna, et. al., Methane Contamination of Drinking Water Accompanying Gas-Well Drilling and Hydraulic Fracturing , 108 NAT'L ACAD. OF SCI. PROC. No. 20 8172-76 (May 17, 2011)., available at http://www.pnas.org/content/early/2011/ 05/02/1 100682108.full:pdf?with-ds=yes.

45. Id. (" $[\mathrm{u}] \mathrm{p}$ to one million wells in Pennsylvania alone.").

46. Smith, supra note 36 , at 139 ("storm water has a great potential to carry contaminates from drilling operations to lakes, streams, and groundwater ... drilling and fracking operations can alter the natural flow of storm water and allow contaminates to be introduced to ordinary storm-water runoff."). But see CHARLES G. GROAT AND THOMAS W. Grimshaw, ENERgy INSTITUTE at UNIVERSITY OF TEXAS AT AUSTIN, FaCt-Based Regulation for Environmental Protection in Shale Gas Development 18 (2012) available at http://energy.utexas.edu/images/ei_shale_gas_regulation120215.pdf ("[T] here is. . little or no evidence of groundwater contamination from hydraulic fracturing of shales at normal depths.").

47. Smith, supra note 36 , at 140.

48. Osborna, supra note 44 ("[A]lthough dissolved methane in drinking water is not currently classified as a health hazard for ingestion, it is an asphyxiant in enclosed spaces and an explosion and fire hazard.").

49. Id. 
areas near active drilling had a methane concentration seventeen times higher than the water samples from shallow wells that were not near active drilling sites. ${ }^{50}$ In Gasland, Josh Fox documents several other stories of likely methane contamination in ground water as a result of fracking. ${ }^{51}$ After Mr. Fox received an offer from a natural gas company to lease his family's land in Milanville, Pennsylvania for $\$ 100,000$, he decided to seek more information about the fracking process and gas drilling that was being conducted underneath the land in Pennsylvania's Marcellus Shale. ${ }^{52}$ During his quest, he discovered evidence of groundwater contamination related to hydraulic fracturing wells that were near the homes of many people he visited around the country. ${ }^{53}$ One family he visited in Dimock, Pennsylvania, complained of health issues related to potential groundwater contamination. ${ }^{54}$ More shockingly, he was able to light their tap water on fire by simply holding a flame underneath a stream of water from their kitchen sink. ${ }^{55}$ Mr. Fox also visited Lisa Bracken in Garfield County, Colorado. There he documented evidence of natural gas seeping into her land as a result of hydraulic fracturing from EnCana Oil \& Gas in the nearby West Divide Creek wetland area. ${ }^{56}$ Furthermore, the Natural Resources Defense Council ("NRDC") has documented dozens of other incidents from people across the United States complaining of groundwater contamination resulting from nearby fracking drill sites. ${ }^{57}$

\section{Seismic Interruption as a Consequence}

There are some studies suggesting that the high-pressure fluid injection process involved in fracking may destabilize underground formations and cause earthquakes. ${ }^{58}$ In general, a link has been shown between fracking and induced seismicity, or earthquakes caused by human activities, as well as the development of hydrocarbon, mineral, and geothermal resources; other causes include waste injection, water filling

50. Id. (Generally, the wells that tested higher for methane concentration were located 1000 meters or less from the drilling site while those that tested much lower for methane concentration were between 4000 and 6000 meters away from a drilling site).

51. GASLAND, supra note 17.

52. Id.

53. $I d$.

54. Id.

55. Id.

56. $I d$.

57. See generally Amy Mall, Incidents Where Hydraulic Fracturing Is a Suspected Cause of Drinking Water Contamination, NRDC.ORG (Dec. 19, 2011), http://switchboard.nrdc.org/ blogs/amall/incidents_where_hydraulic_frac.html.

58. See generally Craig Nicholson and R.L. Wesson, EarthQuake hazard ASSOCIATEd WITH DeEP WELl INJECTION - A RePORT TO THE U.S. ENVIRONMENTAL Protection Agency (U.S. Geological Survey Bulletin 1951). 
large surface reservoirs, underground nuclear explosions, and large-scale construction projects. ${ }^{59}$ Scientists have documented through studies that hydraulic fracturing induces microearthquakes. ${ }^{60}$ Furthermore, scientists are continuing to investigate tremors potentially linked to fracking. ${ }^{61}$ Recently, seismic disruptions in Ohio made national news with links to hydraulic fracturing. ${ }^{62}$ John Armbruster, a renowned seismologist with LamontDoherty Earth Observatory, part of Columbia University, stated that the 2.7 magnitude earthquake that struck Youngstown, Ohio on Christmas Eve 2011 was located one kilometer from the bottom of a fracking well. He suggested that there was sufficient evidence that the pumping of frac fluid into the well caused the earthquake. ${ }^{63} \mathrm{~A}$ week after the first earthquake, a second 4.0 magnitude earthquake struck the area, resulting in the Ohio Department of Natural Resources shutting down the fracking and injection well sites. $^{64}$

\section{Wastewater Deposits, Air Pollution, and Other Concerns}

Many pro-industry studies cite that the chemicals used in the hydraulic fracturing process are in "items that people encounter in their daily lives" such as swimming pools, cosmetics, preservatives, and household cleaners. ${ }^{65}$ On the contrary, the average United States citizen does not encounter the vast amounts of the chemicals necessary in widespread fracking development, nor does the average citizen "consider mixing them with water and injecting them into the ground."66 Furthermore, according to the Environmental Protection Agency ("EPA"), some of the chemicals used in extraction, in their pure form, contain carcinogens and could be fatal if swallowed. ${ }^{67}$ At the end of the fracking process, consideration should be given to uses of the left over water.

59. Vitaly V. Adushkin, et. al., Seismicity in the Oilfield (Summer 2000), available at http://www.slb.com/ /media/Files/resources/oilfield_review/ors00/sum00/p2_17.ashx.

60. See generally, Ying-Ping Li, Microearthquake Analysis for Hydraulic Fracture Process, 9 ACTA SEISMOLOGICA SINICA, 377, 377-87 (1996).

61. Earthquakes Could Be Linked to B.C. Gas Drilling: Seismologist Says 'Seismic Swarm' Should Be Investigated, CBS NEws, Sept. 29, 2011, http://www.cbc.ca/news/canada/ british-columbia/story/2011/09/28/bc-fracking-gas-earthquakes.html.

62. All Things Considered: Fracking Byproducts May Be Linked to Ohio Quakes (NPR radio broadcast Jan. 3, 2012) (transcript on file with Indiana International and Comparative Law Review).

63. Id. (pointing out that the earthquake was probably not caused from the fracking site itself, but was caused from the pumping of used fracking fluid into a deep-injection disposal well located a few miles from the fracking site).

64. Id.

65. Adam J. Bailey, The Fayetteville Shale Play and the Need to Rethink Environmental Regulation of Oil and Gas Development in Arkansas, 63 ARK. L. REV. 815, 824 (2010).

66. Id.

67. Id. 
Fracking for gas yields an enormous amount of wastewater. ${ }^{68}$ The frac fluid that swells back to the surface of the earth at the end of the fracking cycle is known as "flow-back water." 69 The flow-back water is waste, and it is contaminated with a variety of highly toxic chemicals used in the initial frac fluid. ${ }^{70}$ It is estimated that approximately twenty to forty percent of the water used for fracking returns to the surface as flow-back water within two to three weeks of the frack, which accounts for approximately 900,000 to 2.1 million gallons of water from each well. ${ }^{71}$ This water has to go somewhere, so most of it is eventually dumped into injection wells (also called holding ponds) that are often adjacent to the drill site and which are often lined with tarps. ${ }^{72}$ The biggest concern for flow-back water sitting in holding ponds is the surface evaporation of volatile organic compounds (VOCs) which can affect air quality and produce ground level ozone. ${ }^{73}$ Some of the wastewater is placed in metal canisters and is hauled away from the frack site - usually along busy roads, across crowded intersections, and through residential neighborhoods. ${ }^{74}$ This can greatly increase the risk of an accidental spill, which would be catastrophic for the areas in which the spill could occur. ${ }^{75}$ It is also not uncommon for the injection well tarps to leak, causing groundwater contamination of flow-back water. ${ }^{76}$ Finally, some of the contaminated flow-back water is taken to water treatment plants that are not designed to process the chemicals and radiation found in fracking fluids. ${ }^{77}$

In addition to water contamination, the negative impact of hydraulic fracturing on air quality is so serious that the EPA is proposing new regulations to address the impacts on air quality from oil and gas drilling with a specific emphasis on hydraulic fracturing at gas wells. ${ }^{78}$ Specifically, the rules revise New Source Performance Standards (NSPS) for VOCs, sulfur dioxide $\left(\mathrm{SO}_{2}\right)$, and controls on toxic air pollutants released at oil and

68. Smith, supra note 36 , at 134.

69. Id.

70. Id.

71. Id. at 135 .

72. Id.

73. Kimball, supra note 20.

74. Id. See also GASLAND, supra note 17.

75. GASLAND, supra note 17.

76. Smith, supra note 36 , at 135 .

77. Kimball, supra note 20.

78. Adam Orford, Hydaulic Fracturing: Legislative and Regulatory Trends, 279 ENV. Couns. NL. 2 (2011) ("[A]ccording to the EPA, the oil and gas industry accounts for $40 \%$ of the nation's methane emissions, and EPA's VOC NSPS proposal would also capture, burn off, or otherwise significantly limit methane emissions...."). See also Oil and Natural Gas Sector: New Source Performance Standards and National Emission Standards for Hazardous Air Pollutants Reviews, 76 Fed. Reg. 52738 (August 23, 2011) (to be codified at 40 C.F.R. pts. 60 and 63) [hereinafter Oil and Natural Gas]. 
gas wells. ${ }^{79}$ Most industry experts agree that the highlight of this rule is a projected twenty-five percent decrease in VOCs industry-wide by requiring that new or refractured wells capture methane and other gases typically released during the flow-back period by fitting the wells with gas capturing equipment. ${ }^{80}$ Furthermore, a study released from Cornell University concluded that "methane venting during flow-back recovery could offset any greenhouse gas (GHG) gains . . . and render fracking gas even dirtier than coal. ${ }^{, 81}$ Before this study, it was generally accepted by most scientists in the field that natural gas contained significantly lower levels of greenhouse gases than coal and other fossil fuels. ${ }^{82}$ This development seriously undermines the arguments from many pro-industry advocates that hydraulic fracturing is "greener" for the environment in terms of its lasting carbon footprint.

\section{CURRENT REgULATIONS OF FRACKING}

\section{A. Safe Drinking Water Act}

Congress passed the Safe Drinking Water Act (SDWA) in 1974 as a way to regulate the nation's drinking water supplies and protect the public health. ${ }^{83}$ The SDWA requires the EPA to establish regulations and minimum standards to protect tap water and requires all owners or operators of public water systems to comply with these primary (health-related) standards. $^{84}$ Furthermore, the SDWA requires the EPA to develop regulations for the underground injection of fluids in order to protect underground sources of drinking water (USDWs) ${ }^{85}$ The SDWA sets the standards for an underground injection control (UIC) program, and the states are granted the authority to develop their own UIC programs as long as they comply with the standards set under the SDWA. ${ }^{86}$ At 40 C.F.R. $\$ 144.1$, the EPA has set forth specific requirements for the UIC programs

79. Orford, supra note 78 , at 4 .

80. Id.

81. Id. See also Robert W. Howarth et. al., Methane and the Greenhouse-Gas Footprint of Natural Gas from Shale Formations (2010), available at http://www.sustainablefuture.comell.edu/ news/attachments/Howarth-EtAl-2011.pdf.

82. Orford, supra note 78 , at 4.

83. Wes Deweese, Fracturing Misconceptions: A History of Effective State Regulation, Ground-Water Protection, and the IIl-Conceived FRAC Act, 6 OKLA. J. L. \& TECH. 49, 9 (2010). See also EPA, Safe Drinking Water Act Basic Information, available at http://www.epa.gov/lawsregs/laws/sdwa.html.

84. 42 U.S.C § 300g-3 (1974). See also, EPA, Safe Drinking Water Act Basic Information, available at http://www.epa.gov/lawsregs/laws/sdwa.html.

85. Deweese, supra note 83 , at 9.

86. Id. See also EPA, Underground Injection Control Program Federal UIC Regulations, available at http://water.epa.gov/type/groundwater/uic/index.cfm. 
through the authority granted by the SDWA. ${ }^{87}$ The SDWA, under $\S 300-1$, also requires the EPA to:

establish a maximum level for a given contaminant and create a 'national primary drinking water regulation ... if the Administration determines that-' (1) the contaminant may adversely affect human health; (2) there is a 'substantial likelihood' that the contaminant will permeate the public water systems at a rate and quantity that stimulates concerns; and (3) 'in the sole judgment of the Administrator, regulation of the contaminant presents an opportunity to reduce the risks to human health. ${ }^{88}$

If the EPA seeks to adopt a regulation of a contaminant that it determines meets these three permissive elements, it must first conduct research and present analysis on the "health risk reduction benefits.

\section{Problems with the Lax Regulation}

There are serious concerns pertaining to the EPA's regulations regarding UICs and what regulations it adopts protecting USDWs. First, the SDWA did attempt to safeguard capricious research efforts on the EPA's part by requiring the Administrator to base agency decisions on the "'best available, peer-reviewed science' and other relevant public information." 90 However, this standard is seriously inadequate because it allows the Administrator to simply rely on data collected by "accepted methods or best available methods" without ever defining what "accepted" or "best available" means. ${ }^{91}$ Further, it allows the Administrator essentially free range in accepting whatever research it wants by allowing the Administrator to "engage in a circular process of assessment; it is free to select 'accepted' research that supports its hypothesis, while discarding the rest" that it deems to contradict its desired outcome. ${ }^{92}$ This assertion is evidenced in the EPA's 2004 UIC of coalbed methane program study. ${ }^{93}$ During the study, the EPA "conducted minimal amounts of original research, and selected only those reports that catered to the conclusion that the administration sought to reach - that hydraulic fracturing 'poses little or no threat to

87. 40 C.F.R. $\S 144.1$ (2009). See also Deweese, supra note 83, at 9.

88. Cupas, supra note 1 , at 612 . (quoting 42 U.S.C. $\S 300 \mathrm{~g}-1$ (b)(1)(A)(i)-(iii)(2000)).

89. Cupas, supra note 1 , at 612 .

90. Id. (quoting 42 U.S.C. $\S 300 \mathrm{~g}-1(\mathrm{~b})(2)(\mathrm{A})-(\mathrm{B})(2000)$ ).

91. Cupas, supra note 1 , at 612 . (quoting 42 U.S.C. $\$ 300 \mathrm{~g}-1$ (b)(3)(A)(ii)(2000)).

92. Cupas, supra note 1, at 612-13.

93. Id. at 613 . 
USDWs and does not justify additional study. . ."94 Moreover, the EPA "conveniently refrained from including reports from nationally-renowned scientific laboratories, such as the Argonne National Laboratory... [which] concluded that several chemicals frequently used in the extraction process 'can be lethal at levels as low as 0.1 parts per million,' a statistic never cited in the EPA's 2004 UIC program study." ${ }^{.95}$ Furthermore, Congress expressly left ambiguities in the SDWA regarding the UIC programs and instead relied on the EPA to fill in these areas with greater regulations. ${ }^{96}$ Under $\$ 300 \mathrm{~g}-1$, the "EPA has the sole discretion under section $300 \mathrm{~h}$ of the SDWA to...authorize state UIC program proposals." prohibits the EPA from interfering with the "'underground injection of ... fluids which are brought to the surface in connection with oil or natural gas storage ..." "unless such regulation is "essential" to protecting the safety of USDWs. ${ }^{98}$ However, under this portion of the statute, the EPA has broad discretion in determining what is essential because the statute specifies that underground injection will "'endanger' USDWs when it can 'reasonably be expected' to expose a public water system to 'any contaminant." the EPA, under the Bush Administration, interpreted this part of the statute as prohibiting it from further exploration regarding the regulation of hydraulic fracturing, and it stated that hydraulic fracturing presented no “"significant potential threat to USDWs." "100

\section{2. $\operatorname{LEAF~(I)~and~(II)~}$}

The EPA's failure to take action on hydraulic fracturing and UIC programs and the agency's arbitrary action toward them is further shown in the cases Legal Environmental Assistance Foundation v. EPA (I) and (II) (LEAF I and $L E A F I I) .{ }^{101}$ These are two of the most widely cited appellate

94. Id. (quoting U.S. Envtl, Prot. Agency, Evaluation of Impacts to Underground Sources of Drinking Water by Hydraulic Fracturing of Coalbed Methane Reservoirs, ES-4, ES-12 (2004), available at http://www.epa.gov/OGWDW/uic/wells_coalbedmethanestudy.html).

95. Id. at 613-14. (quoting J.A. Veil et. al., Argonne Nat'l Lab., A White Paper Describing Produced Water from Production of Crude Oil, Natural Gas and Coalbed Methane 7-8 (2004), available at http://www.ead.anl.gov/pub/doc/ProducedWatersWP0401.pdf). See also Lisa Sumi, Oil and Gas Accountability Project, Our Drinking Water at Risk: What EPA and the Oil and Gas Industry Don't Want Us to Know about Hydraulic Fracturing 3, available at http://www.earthworksaction.org/pubs/DrinkingWaterAtRisk.pdf.

96. Cupas, supra note 1 , at 614 .

97. Id. at 615 .

98. Id. (quoting 42 U.S.C. $\$ 300 \mathrm{~h}(\mathrm{~b})(2)(2000))$.

99. Cupas, supra note 1, at 615 . (quoting 42 U.S.C. $\$ 300 \mathrm{~h}(\mathrm{~d})(2)(2000)$ ).

100. Cupas, supra note 1, at 616 (quoting U.S. Envtl. Pro. Agency, Evaluation of Impacts to Underground Sources of Drinking Water by Hydraulic Fracturing of Coalbed Methane Reservoirs, Executive Summary, ES-17 (2004), available at http://www.epa.gov/OGWDW/ uic/wells_coalbedmethanestudy.html).

101. See generally Legal Envt'l Assist. Found., Inc. v. United States Envt'l Protection 
cases regarding the fracking process. ${ }^{102}$ Both were decided by theEleventh Circuit Court of Appeals and have never been heard or decided by the Supreme Court. ${ }^{103}$ Therefore, although the holdings only apply within the Eleventh Circuit, the Court's reasoning is influential in other jurisdictions. $L E A F I$ involved the Legal Environmental Assistance Foundation (LEAF), an environmental group who petitioned to rescind the EPA's approval of an Alabama UIC program, which engaged in unregulated methane gas hydraulic fracturing activities on at least eight separate occasions. ${ }^{104}$ The environmental group contended that EPA's interpretation of the regulation was inconsistent with the plain language of the SDWA because the EPA claimed that the methane fracturing processes were left properly unregulated because their principal purpose was not that of "underground injection," or extraction processes that primarily involve the underground "emplacement" of fluids. ${ }^{105}$ The EPA's main contention was that methane gas production wells, which are used for hydraulic fracturing, did not need to be regulated because the principal function of those types of wells was solely methane gas production rather than the underground emplacement of fluids. ${ }^{106}$ In contrast, "LEAF contended that the EPA's narrow interpretation...involving 'underground injection' was inconsistent with the regulatory requirements under the SDWA, and that hydraulic fracturing must be regulated under every valid state UIC program." 107

The Eleventh Circuit sided with LEAF and found that the methane extraction processes being used by Alabama were "underground injections" for the purposes of regulation. ${ }^{108}$ The court stressed in its opinion that there was clear intent from Congress that "all underground injection be regulated under the UIC programs" and that hydraulic fracturing fit within the statutory definition of "underground injection." 109 More importantly, the court differentiated the hydraulic fracturing process' use of injection against other purposes of injection and the importance of regulation of UIC

Agency (LEAF I), 118 F.3d 1467 (11th Cir. 1997). See generally Legal Envt'l Assist. Found., Inc. v. United States Envt'l Protection Agency (LEAF II), 276 F.3d 1254 (11 th Cir. 2001).

102. See generally EPA, Hydraulic Fracturing Background Information, available at http://water.epa.gov/type/groundwater/uic/class2/hydraulicfracturing/wells_hydrowhat.cfm.

103. Id.

104. LEAF I, 118 F.3d 1467 (11th Cir. 1997). See also, Cupas, supra note 1, at 617.

105. $L E A F 1,118$ F.3d at 1471 (arguing that hydraulic fracturing fell within the regulatory definition of "underground injection" under this portion of the statute.). See also, Cupas, supra note 1, at 618 .

106. LEAF II, 276 F.3d 1254 (11 th Cir. 2001). See LEAFI, 118 F.3d at 1471.

107. Cupas, supra note 1 , at 618 (quoting $L E A F I, 118 \mathrm{~F} .3 \mathrm{~d}$ at 1471).

108. $L E A F I, 118$ F.3d at 1477.

109. Id. at 1475. See Cupas, supra note 1, at $618 \mathrm{n} .88$ (noting that "the court further held that '[n]othing in the statutory definition suggests that the EPA has the authority to exclude from the reach of the regulation on an activity (i.e. hydraulic fracturing) which unquestionably falls within the plain meaning of the definition ...'"Id at 1475.). 
programs when it stated "[regulation] is not limited to the injection of wastes or to the injection for disposal purposes; it is intended also to cover, among other contaminants, the injection of brines and the injection of contaminants for extraction or other purposes." ${ }^{110}$ The court's decision had little time to take effect because "before the court could carry out a writ of mandamus to enforce its holding in $L E A F I$, Alabama threw a monkey wrench into the equation: a revised UIC program, in which the state purported to have implemented restrictions upon hydraulic fracturing." 111

The state of Alabama cleverly revised their UIC program to coincide with a second statutory method of UIC approval by the EPA under the SDWA. $^{112}$ Alabama sought approval for their UIC under $\$ 1425$ of the SDWA, which warrants approval by the EPA where the state demonstrates that its UIC program meets the requirements of SDWA sections 1421(b)(1)(A)-(D), and it represents an effective program to prevent contamination of underground drinking water. ${ }^{113}$ Essentially, the practical difference between this method of approval and the first method, which Alabama failed according to the decision in $L E A F I$, is that the latter requirement is much more flexible. ${ }^{114}$ This allowed the EPA to continue to ignore its duties because it could approve the revised UIC program under $\S 1425$ of the SDWA because it is less restrictive. ${ }^{115}$ Further, since $\$ 1425$ of the SDWA does not explicitly include hydraulic fracturing in the activities eligible for alternative approval, the EPA classified Alabama's refined definition of wells under their modified UIC as Class II type wells which allowed them to fall outside the classification requiring regulation. ${ }^{116}$

Fundamentally, the EPA perceived absence of hydraulic fracturing from $\$ 1425$ as a gap in the statutory scheme, which allowed the EPA to construe this section as applying not only to specific processes used during secondary or tertiary recovery of natural gas, but also generally to techniques and processes, like hydraulic fracturing, broadly related to

110. LEAF I, 118 F.3d at 1475. See Cupas, supra note 1, at 618. See also H.R. Rep. No. 93-1185, at 31 (1974) reprinted in 1974 U.S.C.C.A.N. 6454 (discussing the definition of underground injection and its intended scope).

111. Cupas, supra note 1 , at 619 (summarizing $L E A F I I, 276$ F,3d at 1256 that the revised Alabama UIC program would regulate hydraulic fracturing as a "Class II-like underground injection activity").

112. LEAF II, 276 F.3d at 1257 .

113. Id. at 1257.

114. Id.

115. Cupas, supra note 1 , at 619 . See also 42 U.S.C. $\S 300 \mathrm{~h}-4$ (2000) (defining Class II wells as "wells which inject fluids: (1) which are brought to the surface in connection with natural gas storage operations, or conventional oil or natural gas production and may be commingled with waste waters from gas plants ... unless those waters are classified as hazardous at the time of injection.").

116. Cupas, supra note 1, at 619-20. 
secondary or tertiary recovery. ${ }^{117}$ This allowed the EPA to side-step the ruling of $L E A F I$ and conclude that the process of hydraulic fracturing, while not technically identical to secondary or tertiary recovery of natural gas, is an "analogous" process, and therefore is covered and approved by the alternate approval set forth under $\$ 1425 .^{118}$

The Legal Environmental Assistance Foundation once again brought suit challenging the EPA's interpretation of the statutory language, claiming the EPA's interpretation of $\S 1425$ was contrary to the statute's plain meaning and therefore not in accordance with law. ${ }^{19}$ Further, LEAF claimed that Alabama's revised UIC program had to be rejected until hydraulic fracturing was properly classified and regulated. ${ }^{120}$ LEAF likewise argued that the EPA's statutory interpretation and classification of the Alabama wells as "Class II-like underground injection activities" was contrary to congressional intent. ${ }^{121}$ The Eleventh Circuit, after reviewing all of LEAF's arguments, ruled against LEAF and concluded that none of LEAF's arguments would support setting aside the EPA's determination in the case. ${ }^{122}$ Moreover, the court, conducting a Chevron analysis, found that the EPA's interpretation of $\$ 1425$ was more compelling than LEAF's. ${ }^{123}$ Using statutory construction analysis, the court found that in $\$ 1425$ the phrase "relates to" "does not 'directly' and 'unambiguously' speak to whether a state's program regulating hydraulic fracturing may be approved under $\$ 1425$." 124 Under step two of the Chevron analysis, the court had little trouble concluding that the EPA's decision to subject hydraulic fracturing to approval under $\$ 1425$ was a permissible construction of the statute. ${ }^{125}$

Although this might have seemed like a set-back for LEAF at first, the agency persisted and argued that the EPA's classification of hydraulic fracturing of all coalbeds (indirectly including Alabama's) as Class II-

117. $L E A F I I, 276$ F.3d at 1256.

118. Id.

119. Id.

120. Cupas, supra note 1, at 619-20. See LEAF II, 276 F.3d 1253, 1263 (11th Cir. 2001).

121. LEAF II, 276 F.3d at 1262.

122. Id. at $1265 \mathrm{n} .13$.

123. LEAF II, 276 F.3d at 1259. The Chevron test was formulated by the Supreme Court in Chevron U.S.A. Inc. v. Natural Resources Defense Council , Inc., 467 U.S. 837 (1984), where the Court set forth a legal test for determining whether to grant deference to a government agency's interpretation of a statute it administers. The court will first look to see if Congress has directly spoken on the issue in the statute, and if not, and the statute is ambiguous, the court will determine whether the agency's interpretation is permissible.

124. Id. ("[T] relates to .... any underground injection for the secondary or tertiary recovery of oil or natural gas.") (emphasis added).

125. Id. at 1260 . 
like ${ }^{126}$ underground injection activity was not in accordance with law as set out in 40 C.F.R. $\$ 144.6 .{ }^{127}$ LEAF scored a victory with the court in this aspect of the case because the court agreed that the EPA's decision to classify hydraulic fracturing of coalbeds to produce methane as a Class IIlike underground injection activity was inconsistent with the plain language of 40 C.F.R. \$144.6. ${ }^{128}$ Therefore, the EPA's classification was set aside and remanded for the EPA to determine whether Alabama's revised UIC program complied with the requirement for full Class II wells. ${ }^{129}$ However, the EPA made only minimal efforts to comply with the Eleventh Circuit Court of Appeals ruling and instead conducted a perfunctory "study" from 2000 to $2004 .{ }^{130}$ At the end of the study, the EPA concluded that the injection and extraction of materials into coalbed methane wells posed a small threat to underground drinking water sources. ${ }^{131}$

In June 2004, almost three years after the Eleventh Circuit Court of Appeals remanded LEAF II to the EPA, the agency issued its final determination of Alabama's UIC program and concluded that it complied with the Class II well requirements. ${ }^{132}$ The ruling was announced after the agency performed the 2004 perfunctory study whereby the agency claimed that the injection of hydraulic fracturing fluids into coalbed methane gas wells poses "little threat to drinking water." ${ }^{133}$ Since 2004, numerous studies and scholarly critiques have shown that the EPA's 2004 conclusion was an extremely lackadaisical approach to a critically important environmental issue. ${ }^{134}$

\section{B. The 2005 Energy Policy Act and the Halliburton Loophole}

In 2005, in response to the $L E A F$ II ruling, Congress passed the Energy Policy Act of $2005 .^{135}$ Then-Vice President Dick Cheney, the former CEO of the frac-heavy company Halliburton, was extremely influential in successfully getting the Energy Act passed through Congress,

126. Id. at 1262 (noting the distinction between class II-like and class II wells because class II-like wells do not have to comply with all the regulatory requirements of full class II wells).

127. Id. (class II wells are "wells which inject fluids: (1) which are brought to the surface in connection with . . . conventional oil or natural gas production . . ; (2) for enhanced recovery of oil or natural gas; and (3) for storage of hydrocarbons."). See 40 C.F.R. $\S$ 144.6(b)(2009).

128. Id. at 1264 .

129. Id. at 1265 .

130. Cupas, supra note 1 , at 621 .

131. Id.

132. Roberson, supra note 28 , at 25.

133. Id.

134. Cupas, supra note 1 , at 608.

135. Roberson, supra note 28 , at 25 . 
which would preclude the EPA from having jurisdiction over the chemicals injected into the ground by companies conducting the fracking process. ${ }^{136}$ Moreover, the passage of section 322 of the Energy Policy Act of 2005 resulted in two consequences with potentially disastrous effects on the environment relating to hydraulic fracturing. First, the legislation exempts companies from having to disclose the exact chemicals used in their "fracking fluids." 137 Specifically, this exemption eliminates lawsuits by western ranchers who find that drilling for methane gas pollutes groundwater by injecting contaminated fluids underground. ${ }^{138}$ Sixteen companies significantly benefit from this exemption from clean water laws: Anadarko, BP, Burlington Resources, ChevronTexaco, ConocoPhillips, Devon Energy, Dominion Resources, EOG Resources, Evergreen Resources, Halliburton, Marathon Oil, Oxbow (Gunnison Energy), Tom Brown, Western Gas Resources, Williams Cos, and XTO. ${ }^{139}$ Interestingly, these companies gave nearly fifteen million dollars to federal candidateswith more than three-quarters of that total going to Republicans. ${ }^{140}$ Moreover, these sixteen companies spent more than seventy million dollars lobbying Congress to obtain this exemption from the SDWA. ${ }^{141}$ Second, the 2005 Energy Policy Act amended Paragraph (1) of $\S 1421$ (d) of the Safe Drinking Water Act ${ }^{142}$ to redefine the term "underground injection." 143 The amended portion of the Act excludes from the definition of underground injection two items: 1) the underground injection of natural gas for purposes of storage, and 2) the underground injection of fluids or propping agents (other than diesel fuels) pursuant to hydraulic fracturing operations related to oil, gas, or geothermal production activities. ${ }^{144}$ As stated previously, this policy was a huge benefit to the "big business" type companies listed. Due to the absence of disclosure and jurisdiction for the EPA, these businesses stood to gain substantially from the economic impact of the deregulation. ${ }^{145}$ Sadly, "the view that exemption[s] ${ }^{146}$ from federal oversight of oil and gas

136. GASLAND, supra note 17.

137. Id.

138. Id.

139. Energy Policy Act of 2005, or "The Halliburton Loophole," http://www.dunkard creekkill.com/?p=94 (last visited Feb. 27, 2012).

140. Id.

141. Id.

142. See also 42 U.S.C. $\S 300 \mathrm{~h}(\mathrm{~d})$.

143. Energy Policy Act of $2005 \S 322,42$ U.S.C. $\$ 15801$ (2005).

144. Energy Policy Act of $2005 \S 322$, see also 42 U.S.C. $\S 300 \mathrm{~h}(\mathrm{~d})(1)(\mathrm{B})(\mathrm{i})$-(ii).

145. See generally Joshua Domer, Cheney's Culture of Deregulation: How Bush Administration Inaction Created the BP Disaster, Center for American Progress (June 9, 2010), http://www.americanprogress.org/issues/green/news/2010/06/09/7900/cheneys-cultureof-deregulation-and-corruption/.

146. These exemptions have been coined the phrase "Halliburton Loophole" because under the leadership of former Chief Executive Officer Dick Cheney Halliburton introduced 
development would lead to increased energy independence and development ... of bridge fuels, like natural gas, prevailed in Congress."

\section{State Regulations}

\section{New York's Moratorium}

Despite the EPA's apparent lack of concern, several states have taken the initiative to develop their own regulations. Currently, New York has a moratorium on fracking. ${ }^{148}$ In December 2010, Governor Patterson issued an executive order prohibiting high-volume hydraulic fracturing of horizontally drilled wells, such as those in the Marcellus Shale region of southern New York. ${ }^{149}$ The moratorium was in place until the New York State Department of Environmental Conservation (NYSDEC) completed a long-delayed Supplemental Environmental Impacts Statement. ${ }^{150}$ Governor Andrew Cuomo indicated in the summer of 2011 that he was considering lifting the temporary ban after the state's Department of Environmental Conservation released a draft of proposed regulations governing fracking, and during the summer of 2012, he firmly established that he was actively seeking to lift the ban. ${ }^{151}$ Prior to Governor Cuomo's summer 2012 press conference establishing his intent to lift the ban, members of the New York legislature proposed several bills to limit or ban fracking entirely. ${ }^{152}$ In January 2012, one New York legislator, Senator Tony Avella, a sponsor of a bill banning hydraulic fracturing, spoke of the imminent necessity of a ban, "[F]racking is the most important environmental issue this state has faced in the past 100 years . . . there is no possible regulation or series of regulations that can stop the one incident that pollutes our water supply for

much of the fracking technology into the fracking industry and further lobbied to have the exemptions placed in the Energy Policy Act of 2005. See Dorner, supra note 145, n. 161.

147. Emily C. Powers, Fracking and Federalism: Support for an Adaptive Approach That Avoids the Tragedy of the Regulatory Commons, 19 J.L. \& POL'Y913, 938-39 (2011).

148. Jon Campbell, New York State Assembly Passes One-Year Fracking Moratorium, GANNETT ALBANY BUREAU (June 7, 2011, 8:59 AM), http://www.wgrz.com/news/article/ 123804/37/Assembly-Passes-One-Year-Fracking-Moratorium.

149. Mary Esch, NY 'Fracking' Ban: Governor David Paterson Orders Natural Gas Hydraulic Fracturing Moratorium For Seven Months in New York, HUFFPOST GREEN (Dec. 12, 2010, 3:34 PM), http://www.huffingtonpost.com/2010/12/13/ny-fracking-ban-david-paterson_ n_ 795730 .html.

150. Orford, supra note 78.

151. Danny Hakim and Nicholas Confessore, Cuomo Will Seek to Lift Ban on Hydraulic Fracturing, HUFFPOST GREEN (June 30, 2012), http://www.nytimes.com/2011/07/01/nyregion/ cuomo-will-seek-to-lift-drilling-ban.html?pagewanted=all\&_r $\mathrm{r}=0$.

152. Orford, supra note 78 at $n$. 14. (Assembly Bill $554 \overline{7}$ would prohibit fracking in New York until the EPA releases its nationwide study on fracking; Assembly Bill 6541 would place a moratorium on fracking for five years until the state conducts its own study; Assembly Bill 5677 would ban fracking permanently within state parklands; and Assembly Bill 7218 and Senate Bill 4220 would ban fracking entirely.). 
1,000 years." ${ }^{153}$ After Governor Cuomo indicated he would seek to lift the ban, experts advised that it would be several months before fracking would resume in the state. ${ }^{154}$

\section{New Jersey's Legislatively Passed Ban}

The New Jersey legislature passed a bill, via super majorities, in June 2011 , to permanently ban fracking throughout the state. ${ }^{155}$ However, the governor issued a conditional veto and instead recommended a one-year ban (moratorium) instead of banning it completely. ${ }^{156}$ Experts say that the legislation is largely symbolic because there is not enough natural gas under New Jersey worth obtaining by drilling. Opponents, however, say New Jersey could send a strong message about the importance of ensuring water quality by enacting a full ban. ${ }^{157}$ The legislature, in early 2012 was faced with considering whether to accept the governor's proposed alternative or to proceed with a veto override. ${ }^{158}$

\section{FRANCE's COMPLETE BAN ON FRACKING}

\section{A. Legislative History and Background}

The rising public concern over hydraulic fracturing in France, as well as the concern among elected officials, compelled the French government to place a moratorium on the exploration of gas and oil shale (mainly in the Paris Basin) in February 2011 until the findings of a joint mission of the General Council of Industry, Energy, and Technology (CGIET) and the General Council of the Environment and Sustainable Development (CGEDD) was conducted and released in April 2011 assessing the environmental and social impacts of fracking. ${ }^{159}$ However, before the study

153. Environmental Groups Rally for a NY Ban on Fracking, AssoCIATED PRESS (Jan. 23, 2012, 7:23 PM), http://www.syracuse.com/news/index.ssf/2012/01/environmental_groups_ rally_in.html.

154. Hakim and Confessore, supra note 151.

155. Andrew Restuccia,

NJ Gov. Christie Vetoes 'Fracking' Ban Proposal, Calls for Moratorium, THE HiLl (Aug. 25, 2011, 2:24 PM), http://thehill.com/blogs/e2-wire/e2-wire/1 78257-gov-christie-vetoesfracking-ban-proposes-one-year-moratorium. See also A.B. 3653, 214th Legis. (N.J. 2011) available at http://www.njleg.state.nj.us/2010/Bills/A4000/3653_Il.PDF and S.B. 2576, 214th Legis. (N.J. 2011) available at http://www.njleg.state.nj.us/2010/Bills/S3000/2576_ I2.PDF.

156. Id.

157. Id.

158. Orford, supra note 78 , at 6.

159. Nat'l Assy. Rep. No. 3392 (2011), available at http://www.assembleenationale.fr/13/rapports/r3392.asp. See also 2011 Nat'l. Assembly Bill Nos. 3283, 3301, and 3283 and 2011 Senate Bill Nos. 377 and 417. 
was even released, there were three bills introduced in the National Assembly and two bills introduced in the Senate, which would have effectively banned hydraulic fracturing, and exploration of oil and gas while repealing the exclusive licenses for those companies already licensed to conduct such research. ${ }^{160} \mathrm{~A}$ report conducted by MM. Michael Harvard and Jean-Paul Chanteguet, members of the National Assembly, which was recorded at the Presidency of the National Assembly on May 4, 2011, indicated that the most serious concerns regarding fracking that the members of parliament should consider are the fracture itself and the rise of the fracking fluid to the surface. ${ }^{161}$ The report stresses that the fracture, created in order to reach the well located in the shale, may extend over a distance that is greater than originally planned. The tiny crevices could even reach more porous upper level aquifers, which can be dangerous since the chemicals in the fracking fluid could seep through the crevices and contaminate the aquifers. ${ }^{16}$

Secondly, the report expressed skepticism over the testimony of profracking industry advocates that the flow-back fluid, extracted at the end of the fracking process, would not leak out of the borehole (the porosity of the sleeve casing and cement) on its way to the surface. ${ }^{163}$ The report states, "During the ascent, a deficiency in the protection of the borehole may allow some substances to pass through the casing and thus directly pollute aquifers or join porous and permeable layers." 164 One of the most interesting arguments advanced in the report was a brief discussion of, and citation to, the April 18, 2011 report of the U.S. House Committee on Energy and Commerce, which listed the findings that of the fluids used in fracking, up to "twenty-nine are known to be carcinogenic or likely to present risks to human health and are considered pollutants capable of damaging air quality." 165

Another major concern the report focused on was the marked disturbance in the initial phase of production; notably, the seemingly "endless stream of trucks and footprints." 166 The French CGIET and CGEDD estimated that a successful fracking well requires between 900 and 1,300 truck trips, to bring/transfer fluids and other necessary equipment.

160. Id.

161. Id.

162. Id.

163. Id.

164. Id. (emphasis added).

165. Id. See also, Minority Staff Of H. Comm. On Energy AND Commerce, 111 th CONG. REPORT ON ChEMICALS USED IN HYDRAULIC Fracturing (April 18, 2011) available at http://democrats.energycommerce.house.gov/sites/default/files/documents/Hydraulic\%20 Fracturing\%20Report\%204.18.11.pdf.

166. Nat'l Assy. Rep. No. 3392 (2011), available at http://www.assembleenationale.fr/13/rapports/r3392.asp. 
This causes a major nuisance for residents, destroys local ecosystems through the repeated passage of heavy vehicles, widening of roads at the expense of local authorities, damage to existing routes, and increased erosion through the creation of new tracks. ${ }^{167}$

Lastly, the report stressed the inability of France to effectively reduce carbon emissions. The report stated:

A study of a teacher of Cornell University, published April 11, 2011, warned against the impact of oil development by hydraulic fracturing on global warming. The study points out that natural gas is mostly methane [and its] effect on global warming is 105 times greater than carbon dioxide over a period of twenty years. Due to the mining used, gas leaks are more numerous than for hydrocarbons operated by simple drilling. Thus, over a period of twenty years, the production of unconventional gas (due to fracking) is more harmful than natural gas, oil, or coal . . France, like all members of the European Union, pledged in 2008 to achieve the Climate Action Plan developed by the European Commission. This plan, known as the name of "three times twenty" provides for a $20 \%$ reduction in emissions of greenhouse gases by 2020 compared to 1990 levels. ${ }^{168}$

This area of the report emphasized that France had a commitment to reduce carbon emissions, and engaging in hydraulic fracturing would not only undermine the commitment but also give the country a black mark in the eyes of the global community. ${ }^{169}$ During the first reading and debate of the bill in the National Assembly, MM. Jean-Paul Chanteguet noted that the balance of greenhouse gas emitted from the fracturing of natural gas is close to or even higher than that of coal. ${ }^{170}$

Various bills to regulate and ban hydraulic fracturing were introduced in the French National Assembly and Senate. Then they were debated in committees in each house and a conference committee consisting of members of each house, and were finally reconciled into one bill and voted on between March 2011 and June 2011. ${ }^{171}$ During the first reading and

167. Id.

168. Id. See also, R. Howarth, et. al., supra note 81 (emphasis added).

169. Nat'l Assy. Rep. No. 3392 (2011), available at http://www.assembleenationale.fr/13/rapports/r3392.asp.

170. 13th Legislature, Regular Session 2010-2011 (May 10, 2011) (statement of MM. Jean-Paul Chanteguet), available at http://www.assemblee-nationale.fr/13/cri/2010-2011/ 20110174.asp.

171. Nat. Assy. Rep. No. 3392 (2011), available at http://www.assemblee-nationale.fr/ 
debate of the bill in the National Assembly, the Minister for Ecology, Sustainable Development, Transportation, and Housing, Nathalie Kosciusko-Morizet, gave testimony stressing that members of the National Assembly should vote for the bill because France does not want the devastated landscapes and contaminated ground water that the United States was experiencing from hydraulic fracturing. ${ }^{172}$ During the hearing, MM. Michel Harvard also stressed that the introduced bills were a means for Parliament to debate the issue because he realized how unclear the issue of fracking was for many members. ${ }^{173} \mathrm{MM}$. Harvard emphasized that the purpose of the bill before the National Assembly was threefold. ${ }^{174}$ First, it aimed to ensure environmental protection and safety against the risks posed by technology that is only slightly improved and consistent with sustainable development. ${ }^{175}$ Second, it intended to address the concern of the French citizens. ${ }^{176}$ Third, it was a first step towards the establishment of an information source for Parliament on the techniques of exploration and exploitation of the subsoil and knowledge of France's energy reserves, which paved a way for the broader debate on the modernization of the Mining Code. ${ }^{177} \mathrm{He}$ also referenced the movie Gasland to the Assembly, indicating that the movie encouraged the mobilization of elected officials and residents associations throughout the country, showcasing the challenge that fracking had become for the country. ${ }^{178}$ Most importantly, MM. Harvard noted the three most egregious risks of hydraulic fracturing that warranted a total ban: the copious amounts of clean water that is used with the risk of groundwater pollution at the time of fracturing and hauling the frac fluid to the surface, the chemical additives which comprised one half percent of the composition of the fluid, amounting to a volume of several tens of cubic meters per well, and finally, the fact that France demonstrated "through the Grenelle Environment Forum and the charter of the environment ... a strong commitment to protecting [the] environment and human health." i79

After a second lengthy debate over mark-ups and sending the bill back to committee, the National Assembly voted to approve the adoption of the bill as it was initially introduced, with 287 votes for passage and 186

13/rapports/r3392.asp.

172. 13th Legislature, Regular Session 2010-2011 (May 10, 2011) (statement of Min. Kosciusko-Morizet), available at http://www.assemblee-nationale.fr/13/cri/2010-2011/20110173. asp.

173. Id.

174. Id.

175. Id.

176. $I d$.

177. 13th Legislature, Regular Session 2010-2011 (May 10, 2011) (statement of MM. Michel Harvard), available at http://www.assemblee-nationale.fr/13/cri/2010-2011/20110173. asp.

178. Id.

179. Id. 
votes against. It then sent the bill to the Senate for consideration. ${ }^{180}$ After the Senate accepted the bill, it was sent to the Committee on Economy, Sustainable Development and Spatial Planning for consideration and markups. ${ }^{181}$ During the Senate committee hearings, the main arguments that were advanced in the National Assembly were addressed: the amount of pressure required for hydraulic fracturing, the dangerousness and toxicity of the products used in fracing fluid, the disadvantages caused by the endless stream of trucks and heavy machinery, and the impact on the landscape. ${ }^{182}$ The committee adopted four of the five major provisions of the bill that the National Assembly had adopted with amendments. ${ }^{183}$ After a review and mark-up of the bill's provisions in a joint National Assembly and Senate committee on June $15,2011,{ }^{184}$ the final bill was sent to the National Assembly where it was adopted on June $21,2011,{ }^{185}$ and to the Senate where it was adopted on June 30,2011 , by a vote of 176 to $151 .{ }^{186}$

After the passage in the Senate, France officially became the first country to pass an outright ban on hydraulic fracturing countrywide. ${ }^{187}$ The French ban on fracking not only made the process illegal in the country, but it also revoked the standing permits that oil and gas companies had in the country to conduct fracking. ${ }^{188}$ France's Environment Minister Nathalie Kosciusko-Morizet said upon the bill's passage, "We are at the end of a legislative marathon that stirred emotion from lawmakers and the public. Hydraulic fracturing will be illegal, and [P]arliament would have to vote for

180. 13th Legislature, Regular Session 2010-2011 (May 11, 2011), available at http://www.assemblee-nationale.fr/13/cri/2010-2011/20110175.asp. For a full discussion and mark-up during the second meeting of the National Assembly see http://www.assembleenationale.fr/13/cri/2010-2011/20110174.asp.

181. 13th Legislature, Regular Session 2010-2011 (May 11, 2011), available at http://www.senat.fr/leg/ppl10-510.html.

182. Min. of the Comm. on Economic, Sustainable Development, available at http://www.senat.fr/compte-rendu-commissions/201 10523/eco.html\#toc4.

183. Id.

184. Joint Comm. Report for the week of June 15, 2011, available at http://www.senat.fr/compte-rendu-commissions/20110614/cmp.html.

185. 13th Legislature, Regular Session 2010-2011(June 21, 2011), available at http://www.assemblee-nationale.fr/13/ta/ta0691.asp.

186. 13th Legislature, Regular Session 2010-2011 (June 30, 2011), available at http://www.senat.fr/leg/tas 10-155.html, see also Tara Patel, France to Keep Fracking Ban to Protect Environment, Sarkozy Says, BloOMBERG BuSINESS WeEK (Oct. 4, 2011), http://www.businessweek.com/news/201 1-10-04/france-to-keep-fracking-ban-to-protectenvironment-sarkozy-says.html.

187. Tara Patel, France to Keep Fracking Ban to Protect Environment, Sarkozy Says, BLOOMBERG BUSINESS WEEK (Oct. 4, 2011), http://www.businessweek.com/news/2011-1004/france-to-keep-fracking-ban-to-protect-environment-sarkozy-says.html.

188. Law No. 2011-835 of July 13, 2011, Journal Officiel de la République Franपaise [J.O.][Official Gazette of France], July 13, 2011, p. 658 available at http://www.martindale.com/ environmental-law/article_Jones-Day_1443058.htm. 
a new law to allow research using the technique." ${ }^{189}$ The actual text of the law reads, under Article I, "Under the Environmental Chapter and the principle of prevention and correction provided for in Article L. 110-1 of the Code of the environment, exploration and mining of oil and gas drilling followed by hydraulic fracturing of the rock are prohibited in this country. "190 Within two months of the enactment of the statute, all permits held by companies conducting fracking were revoked. ${ }^{191}$

\section{B. Public policy rationale, public perception, and what it means for Europe}

During the close of the first debate of the bill in the National Assembly, MM. Jean-Paul Chanteguet, and Min. Nathalie KosciuskoMorizet cited strong public policy rationale for a complete ban on fracking. ${ }^{192}$ MM. Jean-Paul Chanteguet stated to his fellow members that banning fracking would send a clear policy message that France intends to be a leader in energy independence and keep its commitment to mitigating climate change. ${ }^{193}$ Chanteguet stressed that investing heavily in improving energy efficiency and renewable energy would lead France "toward a society of sobriety." ${ }^{194}$ Min. Koscuisko-Morizet closed the debate with statements mirroring the importance of MM. Chanteguet's statements by stressing to her fellow members" $[w]$ hat is the economy, if not to live better, live well, on a planet whose climate is stabilized, in a protected environment and a peaceful social climate? . . . the exploitation of unconventional oil is an activity that is problematic ... it is about groundwater pollution, soil pollution, [and] landscape impact.",195

Furthermore, a recent speech given by French President Nicolas Sarkozy exemplifies the policy rationale offered in the National Assembly and Senate debates that was overwhelmingly persuasive for many parliamentarians in their vote to ban hydraulic fracturing. Sarkozy stated that France will maintain a ban on fracking until there is proof that shale

189. Id.

190. Id. (emphasis added).

191. Id.

192. 13th Legislature, Regular Session 2010-2011 (May 10, 2011) (statements of MM. Jean-Paul Chanteguet and Min. Kosciusko-Morizet), available at http://www.assembleenationale.fr/13/cri/2010-2011/20110173.asp.

193. 13th Legislature, Regular Session 2010-2011 (May 10, 2011) (statement of MM. Jean-Paul Chanteguet), available at http://www.assemblee-nationale.fr/13/cri/2010-2011/ 20110173.asp.

194. Id.

195. 13th Legislature, Regular Session 2010-2011 (May 10, 2011) (statement of Min. Kosciusko-Morizet), available at http://www.assemblee-nationale.fr/13/cri/2010-2011/20110173. asp (Min. Kosciusko-Morizet also referenced similar arguments offered at the beginning of the debate, notably, that there would be increased traffic on pristine landscape and that fracking itself requires an extraordinary amount of water.). 
gas exploration will not harm the environment or "massacre" the landscape. ${ }^{196}$ Sarkozy also stated during an October 2011 visit to Ales in southern France "[d] evelopment of hydrocarbon resources underground is strategic for our country but not at any price . . . this won't be done until it has been shown that technologies used for development respect the environment, the complex nature of soil and water networks." 197

What is important to note about the fracking that was conducted in France is the fact that "according to the EIA, France has shale gas resources only slightly below those of Poland, and more importantly many of those resources in the Paris Basin are more oil, essentially a field analogous to the Bakken Field which has been a primary cause of the twenty dollar-plus gap between Brent and WTI oil prices."198 This is significant because France is seen in many ways as a leader in environmental affairs in Europe. ${ }^{199}$ The fact that the country has such a significant amount of natural gas that could be extracted from the shale by fracking shows that the country took the environmental concerns of scientists and its citizens over the potentially economic benefits of the process. Finally, the American-made documentary Gasland and its depictions of the monstrous consequences of hydraulic fracturing on average citizens, proved to be incredibly persuasive and determinative for many French legislators during the numerous full-body National Assembly, Senate, committee, and joint committee debates. ${ }^{200}$

\section{THE UNITED STATES' INSUBSTANTIAL APPROACHES TO MANAGE HYDRAULIC FRACTURING}

\section{A. The EPA is not an Appropriate Regulator}

As previously discussed in this Note, the EPA's approach to dealing with the environmental consequences related to fracking has been anemic at best. Moreover, many environmentalists are skeptical towards the EPA's willingness to even address hydraulic fracturing. ${ }^{201}$ First, the EPA made minimal efforts to comply with the Eleventh Circuit Court of Appeals

196. Patel, supra note 186.

197. Id.

198. Nick Grealy, Shale Gas and Oil in France, No Hot AIR (Sept. 27, 2011), http://www.nohotair.co.uk/201 1/63-shale-gas/2144-shale-gas-and-oil-in-france.html.

199. See generally, Le Kama, Alain Along, et. al., France and International Environmental Policy, INTERNATIONAL ECONOMICS, (2006), http://www.cepii.fr/anglaisgraph/ publications/economieinter/rev108/rev108g.htm.

200. 13th Legislature, Regular Session 2010-2011 (May 10, 2011) (statement of MM. Michel Harvard), available at http:/www.assemblee-nationale.fr/13/cri/2010-2011/20110173. asp. See also 13th Legislature, Regular Session 2010-2011 (June 1, 2011) (statement of Min. Kosciusko-Morizet), available at http:/www.senat.fr.seances/s201106/s20110601/s20110601006. $\mathrm{html}$ (when speaking in front of the Senate committee).

201. Cupas, supra note 1 , at 625 . 
remand of $L E A F I$, which appeared to compel the EPA towards frac regulation. ${ }^{202}$ Second, most environmentalists agree that the EPA's 2004 study regarding the effects of coalbed methane hydraulic fracturing on the environment was shoddy and wholly inadequate. ${ }^{203}$ The study failed to refer to public comments or incorporate insights from valuable SDWA affiliates, and the study blatantly disregarded 'multiple states' complaints of water contamination as inconclusive proof of a direct relationship between the fracturing and water damage. ${ }^{204}$ Third, in an attempt to assuage the fears of some environmentalists, the EPA entered an agreement with only ninety-five percent of oil and gas operators that engaged in hydraulic fracturing, which asked the industry to voluntarily remove diesel fuel and other toxic substances from some of the frac fluid injected into USDWs. ${ }^{205}$ Predictably, the permissive language of the agreement stunted its potential for becoming a new regulatory control over hydraulic fracturing, in part, because the agreement allowed the companies to resume utilizing the use of diesel fuel additives in hydraulic fracturing fluids injected into USDWs if the oil companies notified the EPA within thirty days after a decision to abandon the agreement. ${ }^{206}$ Companies seized on the weakness of the agreement, and after congressional inquiry into hydraulic fracturing in 2010, it was discovered that twelve of the fourteen companies surveyed injected more than thirty-two million gallons of diesel fuel into fracking wells between 2005 and $2009 .{ }^{207}$ Finally, it seems that "despite numerous complaints from residents of multiple hydraulic fracturing states, related litigation and settlements, legislative proposals, and even federal circuit holdings, the EPA is steadfast in its belief that hydraulic fracturing should remain virtually unregulated under the SDWA.,"208 Furthermore, most of the published literature pertaining to frac fluids discloses nothing regarding the potential environmental or human health impacts of the fluids, and "there is very little documented research on the environmental impacts that result from the injection and migration of these fluids into subsurface

202. Id. at 621 .

203. See generally, id.

204. Cupas, supra note 1, at 621-2.

205. Cupas, supra note 1, at 621 (emphasis added). This agreement was memorialized in the 2003 Memorandum of Agreement (MOA) and established a voluntary agreement among the EPA and three major oil companies. The EPA indicated that these three companies performed ninety-five percent of the hydraulic fracturing operations in the United States, see id.

206. Cupas, supra note 1 , at 621 .

207. James E. Goddard, Recent Developments in Texas, United States, and International Law, 6 TEX. J. OIL GAS \& ENERGY L. 423, 442-43 (2010-2011) (noting that democratic Congressmen Henry Waxman of California and Ed Markey of Massachusetts launched the inquiry).

208. Cupas, supra note 1 , at 626. 
formations, soils, and the like."209

Recently, however, under the Obama Administration, the EPA is taking a somewhat more thorough approach by deciding to conduct a new study regarding the environmental and human health effects of hydraulic fracturing. ${ }^{210}$ In June 2010, the EPA submitted a comprehensive study plan on hydraulic fracturing for public comment. ${ }^{211}$ On November 3, 2011, the EPA released the outlines of the plan, which included an emphasis on the impact of large-scale water withdrawals, aboveground spills of drilling fluids, and the impact the fracturing process itself has had on water quality and quantity in states where tens of thousands of wells have been drilled in recent years. $^{212}$ Unlike the EPA's 2004 cursory study of hydraulic fracturing used in coalbed methane deposits, this study will "look at the entire water lifecycle of hydraulic fracturing in shale deposits, beginning with the industry's withdrawal of huge volumes of water from rivers and streams and ending with the treatment and disposal of the tainted wastewater that comes back out of the wells after fracking." ${ }^{213}$ The study should be completed in 2014 . $^{214}$

Despite the EPA's sudden "change of heart" to issue a new study, which was mandated by Congress, the agency's history and inability to proactively address the serious environmental issues related to hydraulic fracturing should make many environmental groups and their activists skeptical. ${ }^{215}$ The EPA's inconsistencies under different administrations showcase why the agency cannot be trusted to successfully address the problem.

\section{B. Why the States Are Equally Incapable of Regulating Fracking as is the $E P A$}

There are currently twenty-seven states that have laws in place to govern oil and gas drilling production operations. ${ }^{216}$ However, states have

209. Id. at 626-27.

210. Terry W. Roberson, supra note 28, at 25. See U.S. Envtl. Prot. Agency, Hydraulic Fracturing Research Study, (2010), available at http:/www.epa.gov/safewater/uic/pdfs/ hfresearchstudyfs.pdf.

211. U.S. Envtl. Prot. Agency Hydrauliuc Fracturing Research Study, (2010), available at http://www.epa.gov/safewater/uic/pdfs/hfresearchstudyfs.pdf..

212. Dina Cappiello, EPA to Probe Gas Drilling's Toll on Drinking Water, THE Colorado SPRINGS GAZETTE (Nov. 3, 2011), http://www.gazette.com/articles/epa-127870gas-probe.html. See generally Plan to Study, supra note 42.

213. Id. (emphasis added).

214. Id.

215. Id.

216. Goddard, supra note 204 at 443 . These states are the only ones where shale formations with potential natural gas deposits are located, see id. 
not always regulated oil and gas development aimed at protection. ${ }^{217}$ In fact, until about 1939, a majority of well production regulation was aimed at protecting the asset, namely the oil and gas reservoir, not the environment. ${ }^{218}$ While states have since realized that regulation for purposes of protecting the environment and critical water sources is necessary, the regulation has been far from uniform across states, with most regulations tailored to the specific needs and political environment of each individual state. ${ }^{219}$ Moreover, it has become increasingly apparent that many states have not taken seriously the possibility that fracturing itself might cause groundwater contamination. 220

The spectrum of states' policies regarding fracking fall between little regulation ("pro-fracking") on one end to consideration of banning the practice on the other end ("pro-environment"). ${ }^{21}$ New York and New Jersey, by far the most environmental and human health conscious states, lie on the pro-environment end of the spectrum because their legislatures are seriously considering complete bans on fracking statewide. ${ }^{222}$ Some states have taken restrictive approaches without banning, or temporarily pausing, the process. ${ }^{223}$ For example, Colorado's Oil and Gas Conservation Commission (COGCC), which regulates oil and gas drilling in the state, has issued regulations requiring operators who conduct hydraulic fracturing operations to maintain material safety data sheets (MSDS) for each chemical brought to a well site for use during hydraulic fracturing operations. ${ }^{224}$ In contrast to many pro-fracking states that do not require any disclosure of "trade secret" chemical compositions, the COGCC requires companies to maintain the identity of the trade secret chemical product but not the information regarding the individual chemical components of the composition, unless it is necessary to respond to a spill or alleged release of frac fluid into the environment. ${ }^{225}$ States in the middle of the spectrum, including Wyoming and Michigan, have more stringent than average regulations at the onset of the fracking process. ${ }^{226}$ For example, they require companies who drill for oil and gas to identify and keep accurate records of geologic strata that is being penetrated, including formation by name and depth, and the types of cement and casing used for the shell of the

217. Deweese, supra note 83, at 21.

218. Id.

219. Id. See generally, Bob Sheak, Opponents of Fracking Deal with Corporate and Political Obstacles, THE FREE PRESS (Sept. 7, 2011), http://freepress.org/departments/ display/3/2011/4284.

220. Orford, supra note 78, at 4.

221. See generally, Deweese, supra note 83.

222. See supra notes $148-150,155$ and accompanying text.

223. See generally, Goddard, supra note 204.

224. Id. at 439.

225. Id.

226. Id. 
well. ${ }^{227}$

Currently, only two states have implemented regulations regarding air quality control connected with hydraulic fracturing. ${ }^{228}$ Wyoming and Colorado have implemented so called "green completions" which require new and refractured wells to be fitted with equipment that captures methane and other gases released during the flow-back period when the frac fluid is pumped out of the well after injection. ${ }^{229}$

Unfortunately, at the other end of the fracking spectrum lie extremely lax regulations with potentially catastrophic consequences. ${ }^{230}$ Last year, after a lack of a pressure gauge in fracking operations from Chesapeake Energy Corporations caused contamination of drinking water in Pennsylvania, the state refused to mandate pressure gauges for all corporations involved in fracking similar wells. ${ }^{23}$ This is despite requiring such a gauge for Chesapeake and a call from environmental groups to have them required industry-wide. ${ }^{232}$ Conversely, Pennsylvania's next-door neighbor, Ohio, requires that all industries involved in fracking operations place pressure gauges on fracking wells. ${ }^{233}$ Regulations also vary from state to state regarding the type of cement used for wells, how close to drinkingwater sources companies can drill, and how companies can dispose of frac fluid. ${ }^{234}$ Most disturbingly, of all states where fracking is conducted, Pennsylvania is the only state that lets companies dump fracking wastewater into state waterways. ${ }^{235}$ Equally perplexing, Ohio does not require companies to disclose what fracking chemicals are injected into particular wells. ${ }^{236}$

Other factors exemplify the inability of states to effectively and impartially regulate fracking activities. In the most pro-fracking states, lobbying on behalf of the fracking industry outperformed the lobbying industry promoting stricter regulation. ${ }^{237}$ In Ohio, the fracking industry

227. Id.

228. Orford, supra note 78 , at 4.

229. Id. (these are very similar, if not identical, to the new regulations the EPA has proposed). See also Oil and Natural Gas, supra note 78.

230. See generally, Jim Efstathiou Jr. and Mark Niquette, Fracking Opens Fissures Among States as Drillers Face Many Rules, BLOOMBERG (Dec. 23, 2011), http://www.bloomberg.com/ news/print/2011-12-23/fracking-opens-fissures-among-states-as-drillers-face-many-rules.html.

231. Id.

232. Id.

233. Id.

234. Id. For a comprehensive list of regulations by state see FracFocus: Regulation By State, http://fracfocus.org/regulations-state (last visited Mar. 11, 2013). (Click on the individual state of interest and follow the prompt to see the state's regulations).

235. Fracking for Influence, available at $\mathrm{http}: / / \mathrm{www}$.commoncause.org/atf/cf $\% 7 \mathrm{Bfb} 3 \mathrm{c} 17 \mathrm{e} 2-$ cdd1-4df6-92be-bd4429893665\%7D/FRACKING\%20WEBINAR\%20SLIDES\%20120711.PDF.

236. $I d$.

237. $I d$. 
gave almost three million dollars to candidates and political parties from 2001-2011. ${ }^{238}$ In Michigan, a state with a moderate record of regulating fracking, the fracking industry gave over two million dollars to political candidates and parties while spending another three million dollars on individual lobbying. ${ }^{239}$ One of the most shocking examples comes from Ohio where wealthy executives of companies connected to hydraulic fracturing contributed thousands of dollars to the election of Governor John Kasich. ${ }^{240}$ Billionaire brothers William "Bill" Koch and David Koch funneled almost $\$ 130,000$ in personal contributions through a political action committee (PAC) to support Governor Kasich's election in the fall of $2010 .^{241}$

\section{Solutions to the Problem: Two Half Measures That FaIL}

\section{A. Illusory Half-Measure: Have States Adopt Uniform Standards}

One potential solution for dealing with the inadequacies of the stateby-state approach and do-nothing EPA approach is to have states adopt regulations at least as strict as those required under the SDWA in order to obtain federal authorization to control their own underground injection activities. ${ }^{242}$ The SDWA, as a result of being amended by the Energy Policy Act of 2005, exempts the "underground injection of fluids or propping agents (other than diesel fuels) pursuant to hydraulic fracturing operations." 243 This is only a half measure because the only uniform measure states could be forced to adopt would be regulations regarding hydraulic fracturing conducted with diesel fuel. ${ }^{244}$ As a result of this failure to guide the states, companies are still using diesel fuel to conduct their fracking operations. ${ }^{245}$ Between 2005 and 2009, approximately thirty-two million gallons of diesel fuel have been injected into fracking wells

238. Id. (This is estimated to be only a portion of the money spent by the pro-fracking lobbying groups because Ohio's weak lobbying laws failed to capture almost ninety percent of what was spent). See id.

239. Id.

240. Mike Ludwig, Kasich, Koch and Big-Industry Bucks: Why Ohio is the Next Fracking Frontier (Nov. 29, 2011), http://www.truth-out.org/kasich-and-big-industry-buckswhy-ohio-next-fracking-frontier/1322500816.

241. Id. It is interesting to note that after Governor Kasich was elected he signed a law passed by Ohio's Republican-controlled legislature allowing drilling companies to conduct fracking in state parks. See id.

242. Cupas, supra note 1, at 627. See 42 U.S.C. $\$ 300 \mathrm{~h}-(\mathrm{b})$ (2000).

243. Orford, supra note 78 , at 2.

244. Id.

245. Letter from Henry Waxman, Edward Markey, and Diana DeGette, U.S. Representatives, to Lisa Jackson, Administrator, Environmental Protection Agency (Jan. 31, 2011), available at http://democrats.energycommerce.house.gov/index.php?q=news/waxman-markey-and-degetteinvestigation-finds-continued-use-of-diesel-in-hydraulic-fracturing- $\mathrm{f}$ [hereinafter Letter]. 
throughout nineteen states. ${ }^{246}$ Therefore, this uniform approach is illusory and allows states to individually, under their traditional authority, regulate oil and gas production within their borders. ${ }^{247}$

\section{B. Another Half-Measure: The FRAC Act}

Since 2009, legislation has been introduced repeatedly in both houses of Congress to amend the SDWA specifically to include the underground injection of fluids for hydraulic fracturing for oil and gas production ${ }^{248}$ and to compel companies to disclose the chemical constituents of its hydraulic fracturing fluid. ${ }^{249}$ Unfortunately, the $111^{\text {th }}$ Congress was unsuccessful in passing this necessary legislation. ${ }^{250}$ Stand-alone bills in both the U.S. House of Representatives and the U.S. Senate were introduced on June 9, 2009 for the Fracturing Responsibility and Awareness of Chemicals ("FRAC") Act. ${ }^{251}$ More recently, this legislation was proposed as the FRAC Act of $2011 .^{252}$ The proposed law, introduced in Congress for the third time, is similar to the bill introduced in 2009; it would require energy companies to disclose chemicals used in hydraulic fracturing and, importantly, close a loophole that exempts drilling operators from drinking water regulations. ${ }^{253}$ Furthermore, rather than removing the existing exemption, the bill would actually require the EPA to promulgate nationwide minimum requirements for hydraulic fracturing activities conducted at oil and gas wells. ${ }^{254}$ Reps. Jared Polis and Diana DeGette, both from Colorado, and New York's Rep. Maurice Hinchey introduced the measure while calling for more transparency from the energy industry. ${ }^{255}$ The bill is expected to face a similar fate as the previous measures introduced in the $111^{\text {th }}$ Congress that were defeated due to heavy lobbying pressure by the energy industry, which has spent millions of dollars to fight the common-sense rules. ${ }^{256}$ Upon introduction of the FRAC Act of 2011, Representative Polis stated:

246. Id.

247. Orford, supra note 78, at 2.

248. Id. at 3 .

249. Roberson, supra note 28 , at 25.

250. Id.

251. Id. (noting that the bills that were introduced in the U.S. House of Representatives and U.S. Senate were H.R. 2766 and S. 1215, respectively).

252. Bob Berwyn, Energy: The FRAC ACT is Back in Congress, SUMMIT COUNTY CITIZENS VoICE (Mar. 16, 2011), http://summitcountyvoice.com/2011/03/16/energy-the-fracact-is-back-in-congress/. See H.R. 1084, 112th Cong. (2011).

253. Berwyn, supra note 252 .

254. Orford, supra note 78 , at 3.

255. Berwyn, supra note 252 .

256. Id. 
The FRAC Act is a simple, common sense way to answer the serious concerns that accompany the rapid growth of drilling across the country. Our bill restores a basic, national safety-net that will ensure transparency within the industry and safeguard our communities. If there is truly nothing to worry about, then this bill will lay the public's concern to rest through science and sunlight. 25

Representative Polis' statement reflects a moderate approach to the hydraulic fracturing process. The main problem with his stance, and that of some of his other colleagues in Congress, is that the FRAC Act will not go far enough. This was indicative in the statement released by his colleague Diana DeGette when she said that "[t]he FRAC Act takes necessary but reasonable steps to ensure our nation's drinking water is protected, and that as fracking operations continue to expand, communities can be assured that the economic benefits of natural gas are not coming at the expense of the health of their families." ${ }^{258}$ The FRAC Act takes a short-sighted approach to the regulation of hydraulic fracturing. Full disclosure of the chemical composition of fracking fluid and new regulations on the contents and composition of the fluids are certainly a good start - albeit small. ${ }^{259}$ During the introduction of the bill, RepresentativeHinchey's comments alluded to the fact that he regarded the FRAC Act as a stepping stone to additional, stricter regulation when he stated that "[t]he FRAC Act is an important first step toward ensuring that people are protected from the risks of hydraulic fracturing." 260 The companion bill in the United States. Senate, sponsored by Sens. Bob Casey from Pennsylvania and Chuck Schumer from New York, was equally weak. Specifically, the Senate version would require disclosure of the chemical constituents used in the fracturing process, but it would allow companies to skirt the disclosure process for proprietary chemical formulas. ${ }^{261}$ In an attempt to appease some concerned environmentalists and health field professionals, the Senate version did include an emergency provision that requires proprietary chemical formulas to be disclosed to a treating physician, the State, or the EPA in emergency situations where the information is needed to provide medical treatment. ${ }^{26}$ Although it is commendable that current congressional leaders are recognizing the increased public unrest and need for regulation related to fracking, the proprietary chemical formula exemption proposed in the House and Senate bills only encourages companies that do not wish to

258. Id. (emphasis added).

259. Smith, supra note 36 , at 145.

260. Berwyn, supra note 252. (emphasis added).

261. Id.

262. Id. 
disclose potentially harmful chemicals to create "chemical formulas" and label them as proprietary. In theory, the FRAC Act would do much to mitigate some current problems related to the hydraulic fracturing process. In fact, the increased regulation and requirement of non-proprietary chemical disclosure would greatly improve current loopholes in the process that have led to harmful environmental and human health consequences. However, the proposed FRAC Act, in its current form, does not go far enough.

\section{RECOMMENDATIONS}

This Note advocates for the adoption of a complete ban on hydraulic fracturing in the likeness of the ban passed in France through a federally enacted statute. Additionally, this Note calls for greater environmental interest group ${ }^{263}$ involvement in educating the public and lobbying members of Congress regarding the harmful effects of hydraulic fracturing and why a complete ban is necessary.

After weighing all the evidence related to the hydraulic fracturing process, it should become clear to United Statescongressional leaders and others concerned with the health and well-being of humans and the environment that there is only one viable solution to the hydraulic fracturing problem - a complete ban on the practice. The United States, which has long been a leader in environmental affairs, needs to recognize, just as leaders in France have, that the deleterious effects that stem from fracking are simply too great, and the attempts to regulate and curb some of the harmful effects of the process are too inadequate, to allow the continued use of hydraulic fracturing processes. ${ }^{264}$ The fracking study conducted at the request of legislative leaders in France was skeptical of the pro-fracking industry advocates' message that fracking fluids do not contaminate groundwater. ${ }^{265}$ Similarly, United States congressional leaders should be skeptical of pro-fracking industry advocates, especially in light of the Halliburton Loophole and the millions of dollars the pro-fracking industry has spent on election campaigns of United States politicians. It is increasingly clear that the hydraulic fracturing industry would like the public to believe that there is sufficient regulation to maintain a safe

263. Examples of these interest groups include groups like the Sierra Club and individuals like Josh Fox who directed Gasland. See Oregon Sierra Club Blog, Environmental Groups Continue Fight against LNG Fracking: Ask Federal Environmental Agencies to Protest Export Facilities, http://orsierraclub.wordpress.com/2012/03/01/environmentalgroups-continue-fight-against-lng-fracking-ask-federal-environmental-agencies-to-protest-exportfacilities/ (last visited Mar. 14, 2012).

264. See generally GASLAND, supra note 17.

265. Nat'l Assy. Rep. No. 3392 (2011), available at http://www.assemblee-nationale.fr/ 13/rapports/r3392.asp 
environment and that fracking has no harmful effects on human health. However, just as Representative Polis stated when he introduced the FRAC Act of 2011, "there is a growing discrepancy between the natural gas industry's claim that nothing ever goes wrong and the drumbeat of investigations and personal tragedies which demonstrate a very different reality." ${ }^{266}$ His message echoes the statements of French Environment Minister, Nathalie Kosciusko-Morizet, who stated upon passage of France's ban that the realities of hydraulic fracturing are much different from what pro-fracking industry leaders suggest, and contamination of the environment is a reality that is too great a risk for the French people. ${ }^{267}$ The reality is that human health and environmental contamination and destruction are taking place. ${ }^{268}$ Illnesses traced to fracking have been documented in Colorado, Pennsylvania, Arkansas, Wyoming, Alabama, and Ohio. ${ }^{269}$ Furthermore, "disturbing evidence has been revealed to the public demonstrating that millions of gallons of diesel fuel have been pumped into the ground in fracking operations across the country, and that the inability to properly process wastewater from fracking may [be causing the leaching of] radioactive materials into rivers, streams, and the drinking water supply." 270 Therefore, it is time for Congress to introduce, debate, and successfully pass a ban that would eliminate all types of hydraulic fracturing throughout the United States. Many pro-fracking proponents argue that hydraulic fracturing is a "necessary component of a "clean energy future[,]" and that it is needed for the United States to maintain energy independence. ${ }^{271}$ However, recent scientific evidence has repudiated such claims. ${ }^{272}$ Furthermore, the leaders of the United States should take heed just as the legislative and executive leaders in France did in realizing that fracking for natural gas resources should not come at any price to the country, especially when the harmful environmental impacts and documented human illnesses related to fracking outweigh the economic benefit that hydraulic fracturing provided for the country. ${ }^{273}$ France passed a ban on hydraulic fracturing despite testimony during legislative debates that France's economy would benefit significantly from the removal of natural gas from the Paris Basin. ${ }^{274}$ In the French fracking study, MMs.

266. Berwyn, supra note 252.

267. See supra note 195 , and accompanying text.

268. Id.

269. Id.

270. Id. See generally GASLAND, supra note 17.

271. Deweese, supra note 83, at 32.

272. R. Howarth, et. al., supra note 81 .

273. Patel, supra note 186.

274. 13th Legislature, Regular Session 2010-2011 (May 10, 2011) (statement of Min. Kosciusko-Morizet), available at http://www.assemblee-nationaleff/13/cri/2010-2011/20110173. asp. 
Havard and Chanteguet stated that sacrificing environmental values for the sake of securing the economy and energy supplies through fracking was not a gamble the French government should be willing to take. ${ }^{275}$ It is time for the United States government to adopt the same approach as the French.

The legislative leaders in France were greatly persuaded to pass the hydraulic fracturing ban by environmental interest groups rallying and protesting against the use of hydraulic fracturing in the country. ${ }^{216}$ During the legislative debates, the American-made documentary Gasland was mentioned several times when French legislators were debating the necessity of a fracking ban to protect French citizens. ${ }^{277}$ Overall, the environmental interest groups led a successful campaign in France in persuading their legislative leaders to adopt a countrywide ban on fracking. Similarly, environmental interest groups in the United States should learn from the same groups' successes in France and try to replicate the success in the United States. These interest groups can be successful by holding more public protests and continuing to lobby individual members of Congress to pass a ban. ${ }^{278}$

Finally, history has indicated that piecemeal and overly lenient regulation of the hydraulic fracturing process by the states, federal legislation, and the EPA has been seriously deficient in addressing the destructive consequences hydraulic fracturing has caused. Tighter regulation will not solve the problem. The process itself is the problem. Therefore, to truly protect the health of the citizens of the United States and the country's cherished environment, a complete federal ban on hydraulic fracturing, mirrored in the form of the French statute, must be enacted.

\section{CONCLUSION}

Although hydraulic fracturing has been in use for several decades, it is only recently that the process has been closely scrutinized. New advances in technology have made the process easier to extract natural gas deposits located deep within the earth's shale deposits - but not without serious harmful side effects on the environment. France has led the way in the environmental skepticism of hydraulic fracturing by passing a ban prohibiting the process in any area of the country. The United States has taken smaller, less effective approaches to the harmful effects of hydraulic fracturing mostly by leaving the regulation of fracking to the states. This

275. Id.

276. See generally 13th Legislature, Regular Session 2010-2011(June 21, 2011), available at $\mathrm{http}: / / \mathrm{www}$.assemblee-nationale.fr/13/ta/ta0691.asp.

277. See supra note 176.

278. For an example of how such groups are being successful on the state level see Mary Esch, Groups in Albany Rally against Fracking, WIVB (Apr. 11, 2011), http://www.wivb.com/ $\mathrm{dpp} /$ news/new_york/Groups-in-Albany-rally-against-fracking. 
approach has led to severe harmful effects throughout the United States including air pollution, ground water contamination, and even small earthquakes. The United States could limit or even stop completely the harmful environmental side effects resulting from hydraulic fracturing if the country's political leaders would pass a ban on hydraulic fracturing. 


\section{Indiana}

International

\& Comparative

Law Review vol.23 $\quad$ No.3 2013

\section{IIT ROBERT H. MCKINNEY SCHOOL OF LAW \\ INDIANA UNIVERSITY \\ Indianapolis}

\section{Indiana University \\ Robert H. McKinney School of Law}


The Indiana International and Comparative Law Review publishes professional and student scholarly articles in fields of international or comparative law. The Review welcomes submissions of scholarly legal articles on those topics.

The ideas, views, opinions, and conclusions expressed in articles appearing in this publication are those of the authors and not those of the Review or of Indiana University Robert H. McKinney School of Law.

Currently, the Review is published twice per year. The cost of a single issue is $\$ 9.00$, and subscription rate is $\$ 18.00$ per volume. The annual subscription rate for a foreign subscriber is $\$ 21.00$.

Inquiries regarding submission of articles and comments or subscription may be directed to:

Indiana International \& Comparative Law Review

Lawrence W. Inlow Hall

530 West New York Street

Indianapolis, IN 46202

(317) 274-1050

(317) 274-8825(fax)

\section{COPYRIGHT AND FAIR USE}

Copyright (C 2013 by the Trustees of Indiana University

Except where expressly noted in this publication, permission is granted to reproduce, distribute, or display individual works from this publication in whole or in part for nonprofit educational purposes. All copies made, distributed, or displayed for such purposes must carry copyright notice of the author and the source of the work on every copy, and each copy may be distributed only at or below cost. The permission herein granted is in addition to rights of reproduction conferred by Sections 107, 108, and other provisions of the U.S. Copyright Act and its amendments.

The Review is printed and distributed by Western Newspaper Publishing, Inc., 537 E. Ohio St., Indianapolis, IN 46204-2173. 


\section{Indiana}

\section{International}

\section{\& Comparative Law Review}

The Indiana International \& Comparative Law Review, published by the Indiana University Robert H. McKinney School of Law since 1991, is a studentedited law journal that provides a forum for the discussion and analysis of contemporary issues in public and private international law. The Review publishes articles by prominent legal scholars, practitioners, and policy makers around the world, as well as student-written notes and comments.

The Review is published twice annually, with a symposium issue devoted to a specific topic of international or comparative law published intermittently. Past symposium topics have included political and social aspects of Italian law, various aspects of Chinese law, and international terrorism in the twenty-first century.

Name

School/Firm/Business

Address

City, State, Zip Code

Subscriptions within the U.S. are $\$ 18.00$ per year and outside the U.S. are $\$ 21.00$ per year. I enclose \$ for subscription(s) to the Indiana International \& Comparative Law Review. Please make your check payable to the Indiana International \& Comparative Law Review.

Mail to: $\quad$ Executive Production Editor Indiana International \& Comparative Law Review Lawrence W. Inlow Hall 530 West Street Indianapolis, IN 46202-3225 



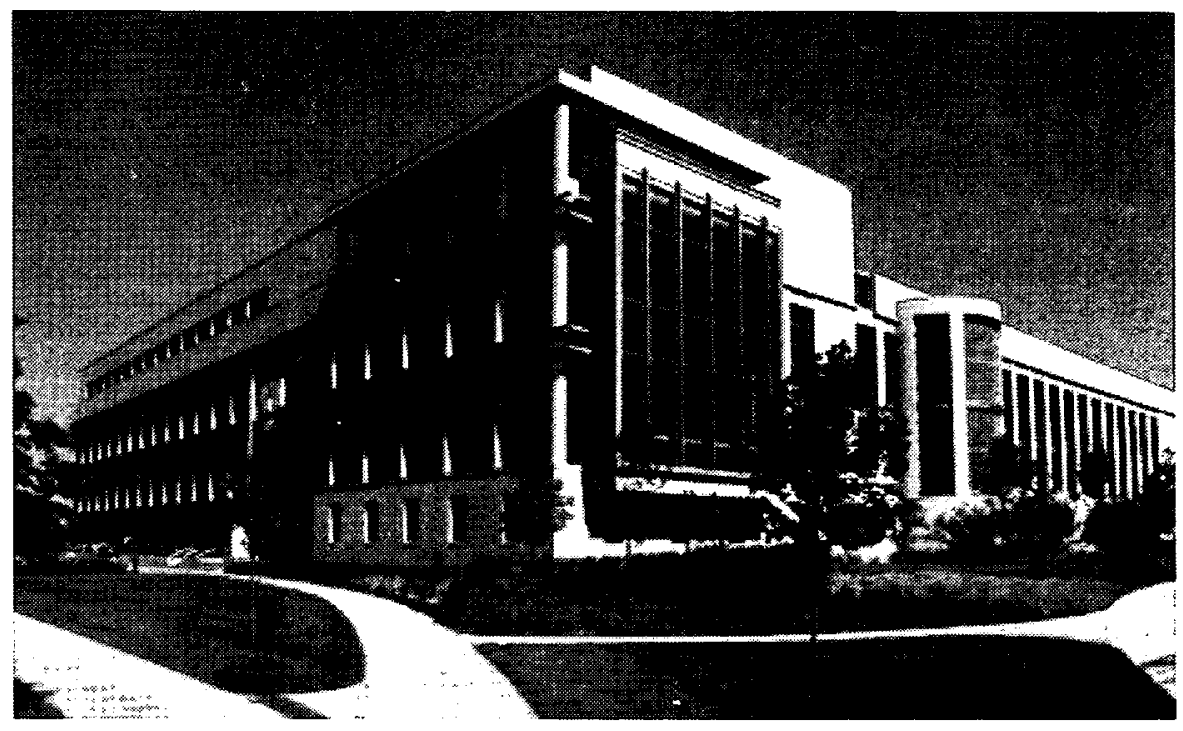

Please enter my subscription

to the

INDIANA LAW REVIEW

Name

Address

Enclosed is $\$$ for subscription(s)

Mail to: ATTN: Editorial Specialist

at

INDIANA LAW REVIEW

INDIANA UNIVERSITY ROBERT H. MCKINNEY

SCHOOL OF LAW

Lawrence W. Inlow Hall

530 West New York Street

Indianapolis, Indiana 46202-3225

For an academic year, the subscription rate for four issues is:

Domestic, \$30; Foreign, \$35; Student, \$20

Single Issue, $\$ 10$; Survey Issue $\$ 20$

Symposium Issue, $\$ 15$ 



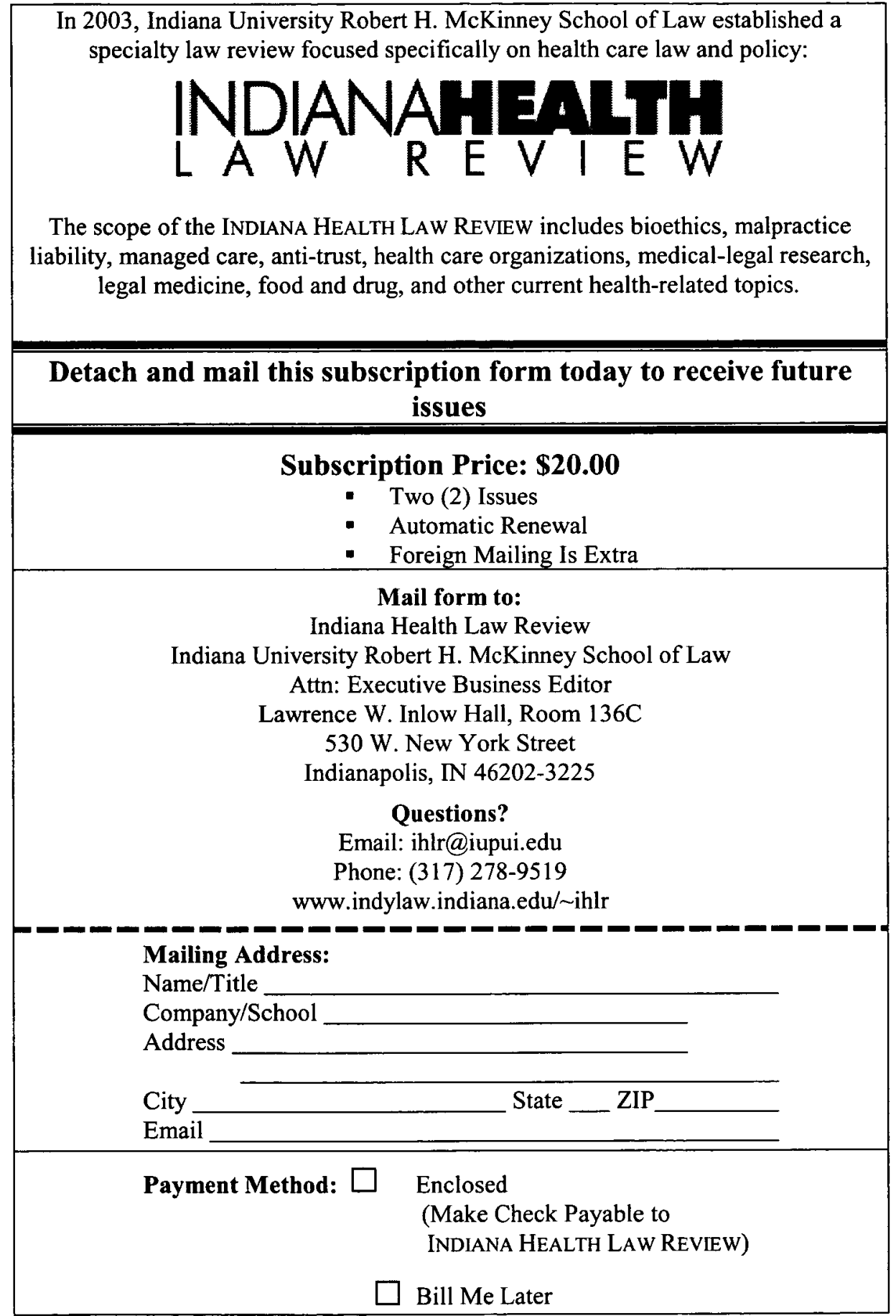





\title{
Indiana University Robert H. McKinney School of Law 2012-2013 ADMINISTRATIVE OFFICERS AND FACULTY
}

\author{
Administrative Officers
}

Michael A. MCROBBIE, President of the University. Ph.D., Australian National University.

CHARLES R. BANTZ, Chancellor, Indiana University-Purdue University-Indianapolis; Indiana University Executive Vice President. B.A., M.A., University of Minnesota; Ph.D., Ohio State University.

GARY R. ROBERTS, Dean and Gerald L. Bepko Professor of Law. B.A., Bradley University; J.D., Stanford University.

Antony Page, Vice Dean, Professor of Law and Dean's Fellow. B. Comm., McGill University; M.B.A., Simon Fraser University; J.D., Stanford Law School.

Karen E. Bravo, Associate Dean for International Affairs, Professor of Law, John S. Grimes Fellow; Dean's Fellow. B.A., The University of the West Indies; J.D., Columbia University School of Law; LL.M., New York University School of Law.

Gerard N. MagliocCa, Associate Dean for Research, Samuel R. Rosen Professor of Law. B.A., Stanford University; J.D., Yale Law School.

JAMEs P. NeHF, Associate Dean for Graduate Studies, Cleon H. Foust Fellow, John S. Grimes Fellow, and Professor of Law. B.A., Knox College; J.D., University of North Carolina Law School.

Jonna Kane MaCDougall, Assistant Dean for External Affairs and Alumni Relations; Adjunct Professor of Law. B.A., M.A., Indiana University; J.D., Indiana University Robert H. McKinney School of Law.

JOHNNY D. PRYOR, Assistant Dean for Student Affairs. B.A., Wittenberg University; J.D., Indiana University Maurer School of Law.

ChASITY Q. ThOMPSON, Assistant Dean for Professional Development. A.S., B.A., Alabama State University; M.B.A., Auburn University; J.D., Indiana University Robert H. McKinney School of Law.

MARK V. WUNDER, Assistant Dean for Development. B.S., J.D., University of Iowa.

JOHN R. SCHAIBLEY, III, Executive Director of the Center for Intellectual Property Law and Innovation and Adjunct Professor of Law. B.A., Purdue University; J.D., Indiana University Maurer School of Law.

ElizABETH Allington, Director of Communications and Creative Services. B.A., Indiana University; M.A., M. Phil., New York University.

TERESA (TERRI) J. Cuellar, Director of Technology Services. B.S., St. Bonaventure University, New York.

BRANDT HERSHMAN, Director of Educational Outreach. Purdue University.

AMANDA KAMMAN, Director of Fundraising and Development Services. B.A., Indiana University.

Patricia K. KInNEY, Director of Admissions. B.S., Purdue University; J.D., Indiana University Robert H. McKinney School of Law.

VIRGINIA MARSCHAND, Director of Administrative and Fiscal Affairs. B.S., Indiana University-Kokomo; M.P.A., Indiana University Purdue University-Indianapolis; J.D., Indiana University Robert H. McKinney School of Law.

SONJA RICE, Director of Special Projects. B.A., Purdue University; J.D., Indiana University Robert H. McKinney School of Law.

AMY K. SPEARS, Director of Major Gifts. B.A., Earlham College.

LAWANDA W. WARD, Director of Pro Bono and Public Interest Programs. B.A., Murray State University; M.A., Illinois State University; M.S., Old Dominion University; J.D., Indiana University Robert H. McKinney School of Law.

JACOB J. MANALOOR, Associate Director for Contracts, Grants \& Fundraising. B.S., Indiana University Purdue University-Indianapolis; J.D., Indiana University Robert H. McKinney School of Law.

ANTHONY MASSERIA, Associate Director for Graduate Programs. B.A., Hanover College; M.S. Ed. Indiana University. 
SEAN Southern, Associate Director, Office of Professional Development. B.A., Ball State

University; M.A., DePaul University; J.D., Loyola University Chicago School of Law.

CARlota Toledo, Associate Director of Student Affairs. A.B., University of Chicago; J.D.,

DePaul University College of Law.

SuSAN K. AGNEW, Assistant Director of Student Affairs. Clark College.

WILliam J. BAKER, Assistant Director of Technology Services. B.S., Purdue University.

SuSAN BuShuE-Russell, Assistant Business Manager. A.A.S., Lakeland College; B.S.,

Eastern Illinois University

AMANDa Gallaga, Assistant Director of Recruitment. B.A., Trinity University.

NOAH JOSEPH, Assistant Director for Graduate Studies. B.A. Miami University; J.D., Indiana

University Maurer School of Law.

KAREN H. MILLER, Assistant Director for Admissions. Midway College.

LISA SCHRAGE, Assistant Director for Donor Relations. B.S., Marian College.

\section{Faculty}

Cynthia M. Adams, Clinical Professor of Law. B.A., Kentucky Wesleyan College; J.D., Indiana University Robert H. McKinney School of Law.

JUDITH FORD ANSPACH, Professor of Law and Director, Ruth Lilly Law Library. B.S., M.L.S., Kent State University; J.D., Mississippi College School of Law.

Cynthia A. BAKer, Clinical Professor of Law and Director, Program on Law and State Government. B.A., J.D., Valparaiso University.

GERALD L. BEPKO, Indiana University-Purdue University-Indianapolis Chancellor Emeritus, Indiana University Trustee Professor and Professor of Law. B.S., Northern Illinois University; J.D., ITT/Chicago-Kent College of Law; LL.M., Yale Law School.

Shawn Boyne, Associate Professor of Law, Dean's Fellow; Grimes Fellow. B.A., Cornell University; M.B.A., University of Minnesota; J.D., University of Southern California's Gould School of Law, M.A., Ph.D., University of Wisconsin; LL.M., Justus-LiebigUniversität.

ROBERT BROOKINS, Professor of Law. B.S., University of South Florida; J.D., Ph.D., Cornell University.

JEFFREY O. COOPER, Associate Professor of Law. A.B., Harvard University; J.D., University of Pennsylvania Law School.

Eric R. Dannenmaier, Professor of Law, Dean's Fellow; Grimes Fellow. B.A., Drury College; J.D., Boston University; LL.M., Columbia University; M. St., Oxford University.

JAMES D. DIMITR, Clinical Professor of Law. B.S., Indiana University; J.D., Valparaiso University School of Law.

JenNifER A. DroBaC, Professor of Law. B.A., M.A., Stanford University; J.D., J.S.D., Stanford Law School.

Yvonne M. DutTon, Associate Professor of Law. B.A., Columbia University; M.A., University of Colorado at Boulder; Ph.D., University of Colorado at Boulder; J.D., Columbia Law School.

George E. EdWARDS, Carl M. Gray Professor of Law; Faculty Advisor to the LL.M. track in International Human Rights Law; Director, Program in International Human Rights Law; John S. Grimes Fellow. B.A., North Carolina State University; J.D., Harvard Law School.

FRANK EMmerT, John S. Grimes Professor of Law and Executive Director, Center for International and Comparative Law. Erstes Juristisches Staatsexamen (J.D.), University of Munich Law School; LL.M., The University of Michigan Law School; Ph.D., University of Maastricht; Diploma, European University Institute.

Nicholas Georgakopoulos, Harold R. Woodard Professor of Law. Ptyhion Nomikis, Athens University School of Law; LL.M., S.J.D., Harvard Law School.

Carrie Hagan, Clinical Associate Professor of Law. B.A., University of Kansas; J.D., University of Cincinnati College of Law.

John LAWRenCE HILl, Professor of Law. B.A., Northern Illinois University; J.D., Ph.D., Georgetown University. 
Max Huffman, Associate Professor of Law; Dean's Fellow. B.A., Cornell University; J.D., University of Cincinnati College of Law.

LaWrence A. Jegen, III, Thomas F. Sheehan Professor of Tax Law and Policy. B.A., Beloit College; J.D., M.B.A., University of Michigan; LL.M., New York University School of Law.

RoBerT A. KATZ, Professor of Law. A.B., Harvard College; J.D., University of Chicago Law School.

Linda Kelly Hill, M. Dale Palmer Professor of Law. B.A., J.D., University of Virginia. Max Huffman, Associate Professor of Law and Dean's Fellow. B.A., Cornell University; J.D., University of Cincinnati College of Law.

ANDREw R. KLEIN, Paul E. Beam Professor of Law; Chief of Staff, Office of the Chancellor of IUPUI. B.A., University of Wisconsin; J.D., Emory University School of Law.

NoRMAN LefsteIn, Professor of Law and Dean Emeritus. LL.B., University of Illinois College of Law; LL.M., Georgetown University Law School.

ALLISON MARTIN, Clinical Professor of Law. B.S., J.D., University of Illinois.

DeBorah MCGREGOR, Clinical Professor of Law and Assistant Director of Legal Analysis, Research and Communication. B.A., University of Evansville; J.D., Georgetown University Law Center.

EMILY MORRIS, Associate Professor of Law and Dean's Fellow. A.B., Harvard University; J.D., University of Michigan Law School.

NOVElla NEDEFF, Clinical Associate Professor of Law. B.A., J.D., Indiana University.

DAVID ORENTLICHER, Samuel R. Rosen Professor of Law and Co-Director of the William S. and Christine S. Hall Center for Law and Health. B.A., Brandeis University; J.D., M.D., Harvard University.

JoANNE OrR, Clinical Professor of Law. B.S., Indiana State University; J.D., California Western School of Law.

MiChaEl J. PITTS, Professor of Law; Dean's Fellow and John S. Grimes Fellow. B.S.J., Northwestern University; J.D., Georgetown University Law Center.

Fran Quigley, Clinical Professor of Law, Health and Human Rights Clinic, Indiana University Robert H. McKinney School of Law; Senior Advisor, Indiana University Center for Global Health. B.A., Hanover College; M.A., Indiana University; J.D., Indiana University Robert H. McKinney School of Law.

FLORENCE Wagman RoISMAN, William F. Harvey Professor of Law. B.A., University of Connecticut; LL.B., Harvard Law School.

JoAn M. RuHTENBerg, Clinical Professor of Law and Director of Legal Analysis, Research and Communication. B.A., Mississippi University for Women; J.D., Indiana University Robert H. McKinney School of Law.

MARGARET RYZNAR, Associate Professor of Law. B.A., University of Chicago; M.A., Jagiellonian University; J.D., University of Notre Dame Law School.

JOEL M. SCHUMM, Clinical Professor of Law. B.A., Ohio Wesleyan University; M.A., University of Cincinnati; J.D., Indiana University Robert H. McKinney School of Law.

LEA SHAVER, Associate Professor of Law. B.A., M.A., University of Chicago; J.D., Yale Law School.

LAHNY R. SILVA, Associate Professor of Law. B.A., M.A., Boston University; J.D., University of Connecticut School of Law; LL.M., University of Wisconsin Law School.

Frank Sullivan, JR., Professor of Practice. A.B., Dartmouth College; J.D., Indiana University Maurer School of Law; LL.M., University of Virginia School of Law.

Margaret C. TARKIngton, Associate Professor of Law. B.A., Brigham Young University; J.D., J. Reuben Clark Law School, Brigham Young University.

NICOLAS P. TERRY, Hall Render Professor of Law; Co-Director of the William S. and Christine S. Hall Center for Law and Health. B.A., Kingston University; LL.M., Corpus Christi College, University of Cambridge.

CaRlton MARK WATERHOUSE, Associate Professor of Law; Dean's Fellow. B.S., Pennsylvania State University; J.D. with honors, Howard University School of Law; M.T.S., Emory University, Chandler School of Theology; Ph.D. with honors, Emory University. 
Frances Watson, Clinical Professor of Law. B.S., Ball State University; J.D., Indiana University Robert H. McKinney School of Law.

LLOYD T. WILSON, JR., Professor of Law; Director, Joint Center for Asian Law Studies; Director, Chinese Law Summer Program; Director, American Law for Foreign Lawyers LL.M. Program. B.A., Wabash College; M.A., Duke University; J.D., Indiana University Maurer School of Law.

DiANA R.H. WINTERS, Associate Professor of Law. B.A., Brown University; M.A., Harvard University; Ph.D., Harvard University; J.D., New York University School of Law.

R. GEORGE WRIGHT, Lawrence A. Jegen III Professor of Law. A.B., University of Virginia; $\mathrm{Ph} . \mathrm{D}$., Indiana University; J.D., Indiana University Robert H. McKinney School of Law.

\section{Emeriti Faculty}

Thomas B. Allington, Professor of Law Emeritus. B.S., J.D., University of Nebraska; LL.M., New York University School of Law.

Edward P. ARCHER, Professor of Law Emeritus. B.M.E., Renesselaer Polytechnic Institute; J.D., LL.M., Georgetown University Law School.

JAMES F. BAILEY, III, Professor of Law Emeritus. A.B., J.D., M.A.L.S., The University of Michigan.

PAUL N. CoX, Professor of Law Emeritus. B.S., Utah State University; J.D., University of Utah College of Law; LL.M., University of Virginia School of Law.

Clyde HaRrison CrocketT, Professor of Law Emeritus. A.B., J.D., University of Texas; LL.M., University of London (The London School of Economics and Political Science).

Debra A. Falender, Professor of Law Emerita. A.B., Mount Holyoke College; J.D., Indiana University Robert $\mathrm{H}$. McKinney School of Law.

David A. FUNK, Professor of Law Emeritus. A.B., College of Wooster; J.D., Case Western Reserve University School of Law; M.A., The Ohio State University; LL.M., Case Western Reserve University; LL.M., Columbia Law School.

Paul J. Galantl, Professor of Law Emeritus. A.B., Bowdoin College; J.D., University of Chicago Law School.

Helen P. GarfielD, Professor of Law Emerita. B.S.J., Northwestern University; J.D., University of Colorado School of Law.

Harold GreEnberg, Professor of Law Emeritus. A.B., Temple University; J.D., University of Pennsylvania Law School.

JefrReY W. Grove, Professor of Law Emeritus. A.B., Juniata College; J.D., George Washington University Law School.

William F. Harvey, Carl M. Gray Professor of Law \& Advocacy Emeritus. A.B., University of Missouri; J.D., LL.M., Georgetown University Law School.

W. William Hodes, Professor of Law Emeritus, A.B., Harvard College; J.D., Rutgers University School of Law-Newark.

William ANDrew KerR, Professor of Law Emeritus. A.B., J.D., West Virginia University; B.D., Duke University; LL.M., Harvard Law School.

ELEANor DeArman KInNEY, Hall Render Professor of Law, Co-director of the William S. and Christine S. Hall Center for Law and Health Emerita. B.A., Duke University; M.A., University of Chicago; J.D., Duke University School of Law; M.P.H., University of North Carolina.

WILLIAM E. MARSH, Professor of Law Emeritus. B.S., J.D., University of Nebraska.

SusAnah M. MEAD, Professor of Law Emerita. B.A., Smith College; J.D., Indiana University Robert H. McKinney School of Law.

H. Kathleen PaTCHel, Associate Professor of Law Emerita. A.B., Huntington College; J.D., University of North Carolina Law School; LL.M., Yale Law School.

Ronald W. Polston, Professor of Law Emeritus. B.S., Eastern Illinois University; LL.B., University of Illinois College of Law.

KeNNETH M. STROuD, Professor of Law Emeritus. A.B., J.D., Indiana UniversityBloomington. 
JAMES W. TORKE, Carl M. Gray Professor of Law Emeritus. B.S., J.D., University of Wisconsin.

JAMEs PATRICK White, Professor of Law Emeritus. A.B., University of Iowa; J.D., LL.M., George Washington University Law School.

LAWRENCE P. WILKInS, William R. Neale Professor of Law Emeritus. B.A., The Ohio State University; J.D., Capitol University Law School; LL.M., University of Texas School of Law.

MaRy Therese Wolf, Clinical Professor of Law Emerita. B.A., Saint Xavier College; J.D., University of Iowa College of Law.

\section{Ruth Lilly Law Library Faculty}

JUDITH FORD ANSPACH, Professor of Law and Director, Ruth Lilly Law Library. B.S., M.L.S., Kent State University; J.D., Mississippi College School of Law.

SUSAN DAVID DEMAINE, Research and Instruction Librarian. B.A., Pennsylvania State University; M.S.L.S., University of Kentucky; J.D., University of Kentucky.

DEBRA DENSLAW, Research and Instruction Librarian. B.A., Franklin College; M.S., University of Illinois, Urbana-Champaign; J.D., Valparaiso School of Law.

RichARD HUMPHREY, Reference Librarian. A.A., Brewton-Parker Junior College; B.A., Georgia Southwestern College; M.L.S., University of Kentucky.

Wendell E. JoHNTING, Cataloging and Government Documents Librarian. A.B., Taylor University; M.L.S., Indiana University.

BENJAMIN J. KEELE, Research and Instruction Librarian. B.A., University of NebraskaLincoln; J.D., Indiana University Maurer School of Law; M.L.S., Indiana University School of Library \& Information Science.

CATHERINE LEMMER, Head of Information Services. B.A., Lawrence University; J.D., University of Wisconsin; M.S., University of Illinois.

ChrIs E. LonG, Cataloging Librarian. B.A., Indiana University; M.A., Indiana University; M.L.S., Indiana University.

MIRIAM A. MURPHY, Associate Director. B.A., Purdue University; J.D., M.L.S., Indiana University-Bloomington. 
. 


\title{
TIJ $\begin{aligned} & \text { ROBERT H. MCKINNEY } \\ & \text { SCHOOL OF LAW }\end{aligned}$ \\ INDIANA UNIVERSITY \\ Indianapolis
}

Indiana International \& Comparative Law Review, Volume XXIII

\author{
Editor-in-Chief \\ ANNE C. KAISER \\ Executive Managing Editor \\ JENNA GERBER
}

Executive Notes Development Editor

ANNE MEDLIN

Executive Articles Development Editor

SPARDHA SAROHA

\section{Executive Symposium Editors}

DOUGLAS LOUKS

MORGAN WHITACRE

\section{Article Editors}

MICHAEL BLACKWELL

CHRISTOPHER JACKSON

JIN KONG
Executive Production Editor
ALEXANDER CRAIG

Executive Notes Editor

NICOLE KELLER

Executive Articles Editor MAYLI

\section{Student Note Editors}

RICHARD MOHR

CHING-SHU WAGNER

ASSOCIATE MEMBERS

ROBERT BERCOVITZ

ZACHARY AHONEN

SUKRAT BABER

TARAH M.C. BALDWIN

JON BURNS

SEAN DENEAULT

DAVID DICKMEYER
ELISA DOLL

STEPHEN REED

\section{MEMBERS}

ANDREW EMHARDT

KYLE FORGUE

SARAH HARRELL

KATELYN HOLUB

NICHOLAS JOHNSTON

MARIANNE LUU
EMMA MAHERN

PATRICK MCINTYRE

KEATON MILLER

ALYSSA TAYLOR

LANE TUTTLE

GRAHAM YOUNGS 


\section{Board of Faculty Advisors}

KaREN BRAVo, ChaIRPERSON

ERIC R. DANNENMAIER

GEORGE E. EDWARDS

FRANK EMMERT

ANTONY PAGE

JOAN M. RUHTENBERG 